\title{
Otel Yöneticilerinin Kullandıkları Güç Kaynaklarının İşgörenlerin Örgütsel Özdeşleşme Düzeylerine Etkisi: Beş Yıldızlı Otel İşletmelerinde Bir Araştırma*
}

\section{The Effect of Power Sources Used by Hotel Managers on Organizational Identification: A Study on Five Star Hotels}

\author{
Prof. Dr. Elbeyi PELIT ${ }^{\text {(D) }}{ }^{1}$, Musa KARAÇOR ${ }^{(D)}{ }^{2}$
}

\begin{abstract}
$\ddot{O} z$
$\mathrm{Bu}$ çalışmanın amacı, otel yöneticilerinin kullandıkları güç kaynaklarının örgütsel özdeşleşmeye olan etkisinin belirlenmesidir. Araştırmada veri toplama yöntemi olarak anket tekniğinden faydalanılmıştır. Araştırmanın evrenini Afyonkarahisar ve Antalya illerinde faaliyet gösteren beş yıldızlı otel işletmeleri işgörenleri oluşturmaktadır. Bu doğrultuda 809 işgören anketi değerlendirmeye alınmış ve elde edilen verilerin analizinde; güvenirlik, yüzde, frekans ve aritmetik ortalama, korelasyon ve regresyon analizleri kullanılmıştır. Çalışma bulgularına göre; yöneticiler en fazla düzeyde yasal güç kaynağını kullanırken, işgörenlerin örgütsel özdeşleşme algıları orta düzeyde belirlenmiştir. Buna ilave Araştırmadan elde edilen bulgularda; yöneticilerin kullandıkları güç kaynaklarının işgörenlerin örgütsel özdeşleşme düzeylerini anlamlı düzeyde etkilediği de araştırmadan çıkan sonuçlar arasındadır.
\end{abstract}

Anahtar Kelimeler: Güç kaynakları, örgütsel özdeşleşme, yönetici, işgörenler, otel işletmeleri

Makale Türü: Araştırma

\begin{abstract}
The aim of this study is to determine the effect of power sources used by hotel managers on organizational identification. In the study, first of all, information is provided as a result of domestic and foreign literature review related to the topics of power sources, organizational identification. Opinions of the employees working in the hotel businesses were obtained by using questionnaire technique. The target population of the study consists of the five star hotels operating in Afyonkarahisar and Antalya cities. In this direction, 809 of hotel employees were assessed and in the analysis of the data obtained, reliability analysis, percentage, frequency and arithmetic mean values, correlation analysis and regression analysis methods were used. According to the findings obtained in the direction of the opinions of employees in hotel businesses, it was found that organizational identification feelings of the employees were moderate, while managers used the maximum legal power source. Analysis of the findings obtained at the end of the study showed that It is also among the result of study that the power sources used by the managers significantly influenced the organizational identification levels of employees.
\end{abstract}

Key Words: Power sources, organizational identification, manager, personnel, hotels

Paper Type: Research

\footnotetext{
* Bu çalışma, Elbeyi PELİT danışmanlığında Musa KARAÇOR tarafından Afyon Kocatepe Üniversitesi Sosyal Bilimler Enstitüsü Turizm İșletmeciliği Anabilim Dalı bünyesinde tamamlanan yüksek lisans tez çalışmasından üretilmiş olup, Afyon Kocatepe Üniversitesi Bilimsel Proje Araştırmaları Koordinasyon Birimi (BAPK) tarafından desteklenmiştir (Proje No: 16.SOS.BİL.11).

${ }^{1}$ Afyon Kocatepe Üniversitesi, Turizm Fakültesi, elbeyipelit@aku.edu.tr.

${ }^{2}$ Afyon Kocatepe Üniversitesi, Sosyal Bilimler Enstitüsü, mkaracor1@gmail.com

Atıf için (to cite): Pelit, E. ve Karaçor M (2021). Otel Yöneticilerinin Kullandıkları Güç Kaynaklarının İşgörenlerin Örgütsel Özdeşleşme Düzeylerine Etkisi: Beş Yıldızlı Otel İşletmelerinde Bir Araştırma. Afyon Kocatepe Üniversitesi Sosyal Bilimler Dergisi, 23(3), 1128-1148.
} 


\section{Giriş}

Turizm işletmelerinin sundukları faaliyetlerdeki başarının en büyük göstergelerinden biri, ürünü satın alan müșterinin üründen sağladığı memnuniyet derecesi olmakla birlikte, işletmenin uzun vadede başarıyı elde etmesinde diğer en önemli faktörlerden biri de işgörenlerin ortaya koydukları performanstır. Çünkü işgörenlerin ortaya koydukları performans, işletmeyi olumlu veya olumsuz olarak etkileyebilmektedirler. Özellikle otel işletmelerinin dinamik yapısı düşünüldüğünde örgüt içerisinde işleyişin sağlanabilmesinde ve hizmet üretiminde insan faktörü belirleyici rol oynamaktadır. Bu işleyişin sağlanmasında bir diğer etken ise güç olgusudur. Güç, bireylere istediklerini elde etmelerinde katkı sağlayan bir aracıdır (Fodor, 1985, s. 1408-1415). Gücün bu aracı görevi, otel işletmelerinde yöneticilerin örgütün hedeflerine ulaşabilmek için işgörenleri yönlendirmek amacıyla kullanılmaktadır. Otel işletmelerinde işleyişin sağlanmasında yöneticilerin payı büyüktür. Ayrıca hizmet odaklı faaliyet gösteren otel işletmeleri için yöneticinin kullandığı güç stili, örgüt sürekliliği ve örgüt performansı açısından belirleyici rol oynamaktadır (Akbaba ve Erenler, 2008, s. 21-36). Yönetici elinde bulundurduğu yönetim biçimini güç kaynakları aracılığıyla örgüt çalışanlarına aktarmaktadır. Üretilen hizmetin kalitesine işgörenlerin etkisi göz önünde bulundurulduğunda işgörenlerin örgüte karş1 geliştirecekleri tutumlar da önem taşımaktadır.

Turizm sektörünün en önemli işletmelerinden olan otel işletmelerinde başarının elde edilebilmesi hizmetin aktarımında en kritik unsur olan insan kaynağının yaptığı işten memnun olmasının önemli bir yeri vardır (Akyüz, Kaya ve Aravi 2015). Çünkü otel işletmelerinde işgören yaptığı işten memnun olduğu oranda daha iyi hizmet üretebilecektir. Otel işgörenlerinin çalıştıkları örgütle bütünlük sağlamaları ve örgütsel özdeşleşme duygularının yüksek olması işgörenin gerek işinden gerekse mensubu olduğu örgütten duyduğu memnuniyetine olumlu yansıyacak bu da örgütün başarı çıktısına doğrudan etki edecektir (İşcan, 2006, s. 162). Böylelikle, örgütün hedeflerini benimsemiş ve örgütün ortaya koyduğu değerlere inanan işgören, üretilen hizmet kalitesinin arttırılmasında en iyi performansını ortaya koymaya gayret gösterecektir. Otel işletmelerinde işgörenlerin örgütsel özdeşleşme duygularının yüksek olmasında özellikle yönetici faktörünün ayrı bir önemi bulunmaktadır. Bu çerçevede örgütsel hedeflere ulaşabilmek için örgüt-işgören ilişkisi iyi incelenmelidir. Bu ilişkinin örgütün ortaya koyduğu hedefler doğrultusunda ilerlemesi için yönetici etkisi iyi belirlenmelidir. İşgörenlerin özdeşleşme duygularının arttırılması ile hedeflere ulaşabilmek daha kolay olabilecektir (Polat, 2009 , s. 17-18). Bu doğrultuda otel işletmelerinde yönetici görevini üstlenen kişilerin kullandıkları güç kaynaklarının işgörenlerin örgütsel davranışlarını önemli derece etkilediğini belirtmek olası olup, bu konu ile ilgili çalışmaların yapılarak öneriler getirilmesi/farkındalık yaratılması önemlidir. $\mathrm{Bu}$ çalışmada otel işletmesi yönelicilerinin kullandıkları güç kaynaklarının işgörenlerin örgütsel özdeşleşme düzeyleri üzerindeki etkinin belirlenebilmesi için beş yıldızlı otel işletmelerinde bir araştırma yapılmış ve bulgular araştırmanın amacı doğrultusunda yorumlanarak ilgili taraflara öneriler geliştirilmiştir.

\section{Kuramsal Çerçeve ve Araştırma Hipotezi}

Güç olgusu, insanoğlunun var olduğu andan itibaren hem sosyal ilişkiler içerisinde hem de mesleki yaşamında karşı1ıklı etkileşimin olduğu her yerde görülmektedir. Bu bağlamda insan ilişkileri içerisinde birinin diğerine olan bağımlılığından doğan güç olgusu varlığını göstermektedir (Bağc1 ve Mohan Bursalı, 2011, s. 9). Güç kelimesi Latince'den (potere) Türkçe'ye geçmiş bir kavramdır. İngilizce karşılığı "power" olarak ifade edilen kavram Türk Dil Kurumu (TDK, 2017) tarafindan; "fizik, düşünce ve ahlak yönünden bir etki yapabilme veya bir etkiye direnebilme yeteneği, kuvvet, efor" biçiminde tanımlanmıştır. Güç kavramı, başkasını kontrol edebilme yeteneği ya da diğer bireylerin tutum ve davranışlarına istenildiği biçimde yön verebilme, etki edebilme, diğer bireylerde istediği doğrultuda değişim oluşturabilme potansiyelidir (Akyüz vd., 2015, s. 74). Bir başka tanımlamayla güç, bir bireyin 
diğer bir bireye bir şey yaptırma, bir şey isteme veya nasıl olacağı hakkında yol gösterme yeteneğidir (Aşan ve Aydın, 2006, s. 267).

Güç kavramı bireylerin hem mesleki hem de sosyal yaşamlarında son derece önemli bir kavramdır. İşletmelerde yöneticilerin aldıkları kararları uygulayabilmesi ve isteklerini yaptırabilmeleri güce bağlıdır (Kayalı, 2011, s. 7). Yöneticinin başarılı olabilmesi elinde bulunan güç kaynaklarını etkili bir biçimde kullanabilmesi ile yakından ilişkilidir. Örgütlerde başarının elde edilebilmesi için yöneticinin sahip olduğu güç kaynağını örgüt hedefleri doğrultusunda kullanması beklenir. Güç kaynakları doğru kullanılırsa yaratacağı etki büyük olacaktır (Schermerhorn, Hunt \& Osborn, 1997). Bireylerin diğer bireyleri etkilemek amaciyla kullandıkları güç kaynakları ile ilgili çok sayıda araştırma yapılmış olmakla birlikte, bu çalışmalar içinde en dikkat çeken ve sonraki araştırmalar üzerinde belirgin bir etkisinin olduğu görülen French \& Raven (1959) tarafindan yapılan çalışmadır. Araştırmacılar gücü; "P'yi etkilemek için O'nun sahip olduğu maksimum potansiyel yetenek" olarak ifade etmişlerdir. Nitekim araştırmacılar güç kaynaklarını birbirinden farklı beş grup altında sınıflandırmışlardır (Bağc1, 2009, s. 4). Bunlar; ödüllendirme gücü (P'nin, O’nun kendisini ödüllendirme yetkisine sahip olduğu yönündeki algılamasına dayanır), zorlayıcı güç (P'nin, O'nun kendisini cezalandırma yetkisine sahip olduğu yönündeki algılamasına dayanır), yasal güç (P'nin, O'nun kendisinin davranışlarını belirleme hakkına sahip olduğu yönündeki algılamasına dayanır), uzmanlık gücü (P'nin, O’nun konusunda uzman olduğu yönündeki algılamasına dayanır), beğeniye dayalı güç (P'nin kendisini $\mathrm{O}$ ile özdeşleştirmesine dayanır) olarak belirtilmiştir (French \& Raven, 1959, s. 152-156).

Yöneticilerin kullandığı güç kaynakları örgüt başarısında etkili olduğu gibi, işgörenler üzerinde de büyük öneme sahiptir. Akyüz vd. (2015), yaptıkları çalışmada örgütlerde yöneticinin kullandığı güç kaynağının iş tatmini üzerinde etkisi olduğunu saptamışlardır. Yapılan bu çalışma, yöneticilerin kullandığ 1 ödüllendirme gücünün ve yasal gücün iş tatmini üzerinde olumlu etkisi olduğunu ortaya koymuştur. Güç olgusu, bütün işletmelerde olduğu turizm işletmelerinde de örgütsel hedeflerin gerçekleştirilmesinde büyük etkiye sahiptir. Gücün ne olduğu ve güç kaynağı kullanımında dikkat edilmesi gerekenlerin belirlenmesi hem örgüt yöneticileri hem de örgüt işgörenleri açısından önem taşımaktadır (Erdoğan, 1997, s. 22). Cömert (2014), çalışmasında yöneticilerin kullandıkları güç kaynakları ile örgütsel bağlılık arasında önemli bir ilişki olduğunu ifade etmiştir. Konuyla ilgili olarak Demir (2017), yöneticilerin kullandıkları güç kaynakları ile örgütsel sinizm arasındaki ilişkiyi vurgu yapmaktadır. Yönetici sahip olduğu güç kaynaklarını doğru biçimde kullanamazsa örgüt çalışanları üzerinde sinizme sebep olabilmektedir. Durum turizm sektörü için düşünüldüğünde yöneticinin örgüt başarısındaki görevi bir kez daha önemini göstermektedir. Yöneticilerin kullandıkları güç kaynaklarının örgüt içinde sahip olduğu önem yapılan çalışmalar (Erkutlu, 2003; Bağc1, 2009; Cömert, 2014; Özhan, 2016; Dirik, 2017 vb.) doğrultusunda anlaşılmaktadır. Öte yandan örgütlerde yöneticiler kullandıkları güç kaynakları ile örgütün başarına doğrudan etki etmektedirler.

Turizm işletmelerinde yaşanan sorunlar arasında özdeşleşmenin sağlanamaması üzerinde durmak gerekmektedir. Örgütsel özdeşleşmenin sağlanabilmesi için örgüt şartları önemli olduğu gibi örgüt yöneticisi de belirleyici role sahiptir. Çakır Titizoğlu (2011), konuyla ilgili gerçekleştirmiş olduğu çalışmada, dönüşümcü liderlik tarzının örgütsel özdeşleşme üzerinde etkili olduğunu ifade etmiştir. Dolayısıyla örgütsel özdeşleşmenin sağlanabilmesinde yöneticinin rolü büyük önem taşımaktadır. Örgütsel özdeşleşme düzeyi yüksek olan çalışanlar yaptıkları işten tatmin olacaklar ve iş tatmin düzeyleri yüksek olacaktır. Bu doğrultuda işlerini severek yapacaklardır (Çakır Titizoğlu, 2011). Yaman (2011), yaptığ çalışma sonucunda örgütsel özdeşleşmenin yöneticilerin liderlik davranışlarından etkilendiğini ve yönetici liderlik davranışlarının çalışanların iş performansına ve işten ayrılma niyetlerine etkilediğini ifade etmiştir. Konuya yönelik bu bulgular örgütsel özdeşleşmenin, işletmeler açısından başarının elde edilmesinde olması gereken bir unsur olduğunu ortaya koymakta ve çalışanlar aracığıyla 
müşterilere sunulan hizmetin kalitesinin arttırılmasında önemli etkiye sahip olduğunu göstermektedir. Bir diğer ifade ile kendini örgüte ait hissedemeyen ve örgütsel bütünlüğün sağlanmadığı örgüt çalışanlarının örgütün başarısı için en iyi hizmeti sunmaya gayret göstermesi beklenemez. Bu doğrultuda örgütle özdeşleşen ve örgütün başarısını kendi başarısı gibi niteleyen çalışan üretilen hizmet kalitesinin arttırılması için daha fazla performans gösterecektir. Çalışanın örgütle özdeşleşmesi ve performansını arttırması örgütsel başarının elde edilmesine olumlu etki edecektir. Örgütsel özdeşleşmenin sağlanamadığı işletmelerde çalışan nezdinde, iş tatminsizliği, işten ayrılma, performans düşüklüğü, örgütsel yabancılaşma gibi olumsuz durumlar olası sonuçlar olarak görülebilmektedir. Bu olumsuz durumların ortaya çıkmaması için turizm işletmeleri açısından özellikle vurgulanması gereken nokta; örgüt yöneticisinin yönetim tarzı ve kullandığı gücün çalışanlar üzerinde örgüt lehine etki bırakmasının sağlanmasına yönelik tedbirlere ağırlık verilmesidir. Nitekim Yeşiltaş (2012), otel işletmelerinde yaptığ 1 bir uygulama sonucunda etik liderliğin örgütsel özdeşleşme üzerinde etkili olduğunu belirtmiştir. Otel yöneticileri etik liderlik düzeylerini yükselttikçe örgütsel özdeşleşme düzeyi de artış göstermektedir. Yöneticilerin kullandığı yönetim biçimi çalışanların örgüte karşı olan tutumlarının belirleyicisidir. Örgüt çalışanlarının örgütün hedefleri doğrultusunda tutum geliştirmeleri için, yönetici sahip olduğu gücü ve yönetim biçimini çalışanlardan en yüksek verimliliği alacak biçimde düzenlemelidir. Karalar (2015), otel işletmelerinde yaptığı çalışmasında ödül yönetimi ile örgütsel özdeşleşme arasında pozitif yönlü bir ilişki olduğunu ifade etmiştir (Karalar, 2015).

Otel işletmelerinde çalışanların yaptıkları işi severek yapmaları ve örgütün başarısını kendi başarıları gibi tanımlamalarının örgütsel özdeşleşmenin oluşturulmasını sağlar. Ancak örgütsel özdeşleşmenin sağlanması için ödüllendirici faaliyetlerde bulunulması hem olumlu hem de olumsuz sonuçlara sebep olabilir. Ödüllendirme, aynı zamanda yöneticilerin kullandıkları güç kaynakları arasında olan ödüllendirici güç kaynağı ile benzerlik gösterebilir. Ödüllendirici güç, yöneticinin isteklerini yerine getirilmesini sağlamak için vaat ettiğinin gerçekleştirilmesidir (Green, 1999, s. 55). Bu noktada dikkat edilmesi gereken durum, turizm işletmelerinde örgütsel özdeşleşmenin taşıdığ1 önem ve örgütsel özdeşleşmenin olası olumlu ve olumsuz etkilerinin belirlenmesidir. Ödüllendirme ve ödüllendirici güç kaynağının kullanılması çalışanların motivasyonlarının artmasında ve performanslarında olumlu etkiye sahip olabilir. Nitekim Wong, Siu \& Tsang (1999), otel işletmeleri üzerinde yaptıkları çalışma sonucunda işgörenlerin ödüllendirme vb. nedenlerle sektörde çalıştıklarını ifade etmişlerdir. Örgütsel özdeşleşmenin sağlanabilmesi için yönetici motivasyonu artırıcı faaliyetlerde bulunabilir. Çünkü turizm işletmelerinde üretilen hizmet kalitesinin arttırılabilmesi ancak çalışanların yaptıkları işi severek yapmaları ve örgütle bütünsel bir yaklaşımla hareket etmeleri sonucu elde edilebilir. Örgütsel özdeşleşmenin sağlanamadığı durumlarda otel işletmeleri pek çok olumsuz durumla karş1 karşıya kalabilirler.

Turizm sektörünün en önemli işletmelerinden olan otel işletmelerinde ortaya çıkacak sorunlara en kısa sürede çözüm oluşturulması müşteri memnuniyeti ilkesi gereği önem taşır (Yarmac1, 2012, s. 59). Bu durum turizm işletmelerini hata payını en aza seviyede tutmaya zorunlu kılmaktadır. En az hatayla faaliyet gösterip, en iyi hizmet kalitesini üretebilmek için öncelikle işletmenin sahip olduğu insan kaynă̆ını en verimli bir biçimde yönetebilmesi gerekmektedir. Hizmet üreten müşteri memnuniyeti odaklı otel işletmelerinde örgütsel başarının elde edilmesi örgütün iyi yönetilmesinden geçmektedir. Otel işletmelerinde en üst düzeydeki yöneticiden, en alt kademedeki işgörene kadar gerekli niteliklere sahip olmayan kişiler söz konusu ise, otel yatırımı istenildiği kadar gelişmiş malzemeyle donatılmış olsun, işletmenin verimli çalışması ve devamlılığı mümkün değildir (Pelit, 2015, s. 61). Dolayısıyla otel işlemelerinde başarının sağlanabilmesi için yöneticilere büyük görev düşmektedir. Otel işletmelerinde yöneticinin başarısı büyük ölçüde astlarına, eş düzeydekilere, üstlerine, rakiplerine, müşterilerine, tedarikçilerine vb. bağlıdır (Erkutlu, 2003). Bu kapsamda otel yöneticilerinin sahip oldukları gücü nasıl kullandıkları ve otel yöneticileri tarafından kullanılan güç kaynaklarının etkilerini tespit etmek yönetici başarısı ve bunun sonucunda örgüt başarısı 
için etkin rol oynamaktadır. Diğer taraftan otel işletmeleri işgörenlerinin, örgütlerine karşı geliştirdikleri tutum ve davranışlar örgüt verimliliğini doğrudan etkilemektedir. Özellikle otel işletmelerinde verimlilik açısından, işgören performansının başlı başına büyük önem taşıması neticesinde, işverenlerin örgüt işleyişi için işgörenden en iyi performansını sağlaması gerekmektedir (Babür, 2009, s. 69). Bu noktada işgörenlerin örgüte karş1 geliştirdikleri tutumları performanslarının belirleyicisi olmaktadır. Dolayısıyla otel işletmelerinde yöneticilerin kullandığ 1 güç kaynaklarının tespiti sektörde mevcut durumun tespit edilmesi ve öneriler getirilmesi açısından büyük öneme sahiptir. Çünkü yönetici sahip olduğu güç unsurları ve yönetim biçimleri ile işletmenin geleceğine yön vermektedir. Yönetici gücünü, hem işgörenlerin örgütsel özdeşleşme duygularını geliştirecek yönde kullanabilmeli hem de işgörenlerden en iyi verimi sağlama noktasında dikkatli olmalıdır. Bu noktada yöneticinin misyonu devreye girmektedir. Otel yöneticileri güçlerini işgörenlerin işletmeye özdeşleşme duygusu içerisine girecek şekilde kullanmalıdır.

Otel işletmelerinin en önemli özelliği hizmet odaklı olması ve bu hizmetin işgörenler aracılığıyla müşteriye ulaştırılmasıdır. Bu noktada sahip olunan insan kaynağının önemi göze çarpmaktadır. Eldeki insan kaynağından etkili biçimde yararlanabilmek için işgörenler örgüte inanmalı ve örgütün belirlediği hedefler doğrultusunda faaliyette bulunmalıdırlar. Bu durumun sağlayıcısı ancak etkin bir yönetici ve etkili bir yönetim felsefesi ile mümkün olabilecektir. Dolayısıyla araştırmada otel yöneticilerin kullandıkları güç kaynaklarının ve bu güç kaynaklarının otel çalışanları üzerindeki etkilerinin belirlenmesi büyük öneme sahiptir.

Örgütler belirli hedefler doğrultusunda bir araya gelen bireylerden oluşmaktadır. Bu bireylerin örgütün belirlediği hedeflere uygun biçimde yönlendirilmesi için hiyerarşiye gereksinim duyulmaktadır. Kurulacak hiyerarşide işleyişi sağlayacak unsur da güç olgusudur (Akyüz vd., s. 71-90). Bu bilgiler örgüt içerisinde işleyişin nasıl sağlandığının örgüt başarısı için taşıdığı önemi bir kez daha ortaya koymaktadır. Örgütün belirlediği hedeflere ulaşabilmesi için işgören-örgüt ilişkilerinin kapsamlı biçimde analiz edilmesi gerekmektedir. Bu veriler örgütsel başarıda kritik faktördür. İşgörenler, örgütün hedeflerini benimsemeli ve kendilerini örgüte aidiyet duygusu içinde performans yansıtmaya hazır hale getirmelidirler. İşgörenlerin özdeşleşme duygularının artırılması ile hedeflere ulaşmak mümkün olacaktır (Polat, 2009, s. 1718). Özdeşleşme duygusunun sağlanmasında yönetici faktörü de belirleyiciler arasındadır. Yönetici, işgörenleri üzerinde bıraktığı etkiler ile özdeşleşme gibi olumlu tutumlara sebep olabilir. Örgüt-işgören bağının iyi kurulması günümüz işletmelerinde pek çok açıdan önem taşır (Çırakoğlu, 2010, s. 12). Örgütsel özdeşleşmenin kurulamadığ 1 işgörenler örgüte karş1 olas1 olumsuz davranışlar sergileme duygusu içine girebilirler. Nitekim kendini örgüte ait hissedemeyen işgören, örgüt hedefleri için olumlu etkiye sahip olmayacaktır. İşgörenler üzerinde oluşan bu durumlarda yöneticinin sahip olduğu etkinin belirlenmesi gerekmektedir. Yöneticilerin kullandıkları gücün işgörenler üzerinde ne gibi yansımaları olduğunun belirlenmesi tercih edilecek güç kaynağının belirlenmesine de etki edecektir.

Turizm sektörünün önemli işletmeleri arasında bulunan otel işletmelerinde sürdürebilirliğin sağlanabilmesi için hizmette kaliteli süreklilik ile mümkün olabilir. $\mathrm{Bu}$ doğrultuda belirli amaçlar için bir araya gelen bireylerin belirlenen yönetici gruplarına ihtiyaçları vardır. Bu yöneticiler yönetim süreleri boyunca örgüte olumlu veya olumsuz olarak direkt etki durumuna sahiptirler. Yöneticiler alt grupları işletmenin hedefleri doğrultusunda yönlendirirler. Bu yönlendirme biçimi kısa sürede işgörenler üzerinde, uzun sürede ise işletme geleceği üzerinde belirleyici rol oynamaktadır. Yöneticinin bu rolü olumlu biçiminde kullanabilmesi güç kullanımı ile mümkün olur. Ancak yöneticinin kullandığı güç seçiminde dikkat etmesi gereken önemli hususlardan birisi kullanılan güç kaynağının işgören üzerinde oluşturduğu etkidir. İşgören taşıdığı önem gereği hizmet üretimi işleyişini sağlayan önemli bir faktördür. İşgörenlerin çalıştıkları işletme ile bütünleşmesi ve örgütü benimsemeleri hedeflere ulaşılmasında ve sürekliliğin sağlanmasında önemli faktörler arasındadır. Örgütsel özdeşleşmenin sağlandığı işgörenlerin örgütün hedeflerine ulaşmasında daha olumlu faaliyetler 
içerisinde olacakları söylenebilir. Yöneticinin kullandığı güç kaynă̆ının işgörene etkilerinin belirlenmesi en doğru güç kaynağının saptanması açısından da fayda sağlayacaktır. Bu kapsamda çalışmanın konusunu; otel işletmelerinde çalışan yöneticilerin kullandıkları söz konusu güç kaynaklarının işgörenlerin örgütsel özdeşleşme düzeylerine etkisinin belirlenmesi oluşturmaktadır. Bu çerçevede araştırmada, beş yıldızlı otel işletmelerinde çalışan işgörenler üzerinde bir uygulama gerçekleştirilmiştir. Böylelikle otel yöneticilerinin kullandığı güç kaynaklarının örgütsel özdeşleşme üzerindeki etkisi ortaya konularak, elde edilen bulgular doğrultusunda ilgili taraflara öneriler getirilmiştir. Bu doğrultuda araştırmanın temel hipotezi şu şekilde geliştirilmiştir:

Hipotez: Otel işletmeleri yöneticilerinin kullandıkları güç kaynaklarının, işgörenlerin örgütsel özdeşleşme algıları üzerinde anlamlı bir etkisi vardır.

Araştırmaya ilişkin yukarıda verilen amaç ve hipotez doğrultusunda araştırmada aşağıdaki sorulara cevap aranmıştır:

- Otel işletmeleri yöneticilerinin kullandığg güç kaynakları nelerdir?

- Otel işletmeleri işgörenlerinin örgütsel özdeşleşme düzeyleri nedir?

- Otel işletmeleri yöneticilerinin kullandığı güç kaynakları ile işgörenlerin örgütsel özdeşleşme düzeyleri arasında anlamlı bir ilişki var mıdır?

- Otel işletmeleri yöneticilerinin kullandığı güç kaynaklarının işgörenlerin örgütsel özdeşleşme düzeyleri üzerinde anlamlı bir etkisi var mıdır?

\section{Yöntem}

Araştırmada veri toplama yöntemi olarak anket tekniğinden yararlanılmıştır. Uygulanan anketin ilk bölümünde otel işletmeleri işgörenlerinin demografik (yaş, cinsiyet, medeni durum, eğitim durumu, gelir) ve diğer bazı bireysel özelliklerini (departman, sektörde çalışma süresi, işletmede çalışma süresi) belirlemeyi amaçlayan 8 kapalı uçlu soruya yer verilmiştir. Anketin ikinci bölümünde beş yıldızlı otel otel işgörenlerinin örgütsel özdeşleşmeye yönelik algılarını belirlemek için yaygın olarak kullanılan Mael ve Ashforth (1992) tarafından geliştirilerek ve literatürde (Çırakoğlu, 2010; Özsöylemez, 2009; Köse, 2009; Yarmacı, 2012) yaygın olarak kabul görüp kullanılan 6 ifade ve tek bir boyuttan oluşan "Örgütsel Özdeşleşme Ölçeği" kullanılmıştır. Anketin üçüncü bölümünde ise otel işletmelerinde çalışan yöneticilerin kullandıkları güç kaynaklarını belirlemeye yönelik; 'uzmanlık gücü (7 madde),", 'beğeniye dayalı güç (7 madde)", '’ödüllendirici güç (7 madde)", '’orlayıcı güç (7 madde)" ve 'yasal güç (7 madde)" olmak üzere 5 boyuttan oluşan Rahim'in (1988) "Liderlik Güç Envanteri" kullanılmıştır. Örgütsel özdeşleme ile ilgili ölçek 5'li Likert ölçeği doğrultusunda derecelendirilmiş olup; 1=Hiçbir Zaman, 2=Nadiren, 3=Bazen, 4=Genellikle ve 5=Her Zaman şeklinde puanlandırılmaya tabi tutulmuştur. Güç kaynakları ölçeği ise 5'li Likert ölçeği doğrultusunda derecelendirilmiş olup; 1=Hiç Katılmıyorum, 2=Az Katılıyorum, 3=Orta Düzeyde Katılıyorum, 4=Çok Katılıyorum, 5=Tamamen Katılıyorum şeklinde puanlandırılmaya tabi tutulmuştur.

Araştırmanın evrenini Afyonkarahisar ve Antalya ili Lara-Kundu bölgesinde faaliyet gösteren beş yıldızlı otel işletmelerinde çalışan işgörenler oluşturmaktadır. Termal turizmde Afyonkarahisar ili büyük bir önem taşımaktadır. Afyonkarahisar sahip olduğu doğal kaynakların yanı sıra mevcut beş yıldızlı otel işletmeleri ile termal turizmde marka değeri olan bir şehirdir. Araştırma bölgesi olarak seçilen diğer il ise oldukça fazla sayıda beş yıldızlı otel işletmesinin faaliyet gösterdiği Antalya Lara-Kundu bölgesinde yer alan beş yıldızlı otel işletmeleridir. Araştırmanın coğrafi olarak seçilen iki bölgesi yapıları gereği elde edilecek sonuçlar bağlamında yapılacak kıyaslamalar ile önem taşımaktadır. Nitekim araştırmanın, bu yönüyle de bölgeye ve ilgili işletmelere katkı sağlaması beklenmektedir. Bu kapsamda araştırma Afyonkarahisar ve Antalya ili Lara-Kundu bölgesinde faaliyette bulunan beş yıldızlı otel 
işletmeleri ile sınırlandırılmıştır Öte taraftan, araştırmanın evrenini oluşturan kişi sayısının çok fazla sayıda olması, buna ilave olarak zaman ve maliyet ve kontrol güçlükleri açısından kısıtlılıklara sahip olunduğundan evrenin tamamına ulaşmanın mümkün olmayacağ 1 öngörüsüyle örneklem alınma yoluna gidilmiştir. Bu bağlamda evrenin tamamı yerine, tabakalı örneklem seçilerek anket uygulaması gerçekleştirilmiştir. Daha önce gerek Afyonkarahisar bölgesinde, gerekse Antalya ilinde otel işletmeleri üzerinde gerçekleştirilen çalışmalar neticesinde ilgili bölgelerdeki otel işletmelerinde çalışan sayılarının oldukça fazla sayıda olması dolayısıyla evren hacminin büyüklüğü $(\mathrm{N}>10.000$ veya $\mathrm{N}<10.000)$, değişkenlerin türü (nitel veya nicel) ve güven düzeyi (1- $\alpha$ ) göz önünde alınıp alınmayacağ 1 gibi kıstasların belirlenmesi için literatürde bulunan (Özdamar, 2003, Ural ve K1lıç, 2013) bazı formüller doğrultusundan uygun örneklem büyüklüğü hesaplanmıştır. Bu doğrultuda bu aşamada evren büyüklüğünün belirlenmesinde Kültür Turizm Bakanlığına ait resmi web sitesinde bulunan şehirler bazında otellerin yatak kapasitelerine göre sahip olduğu personel sayısı saptanmasında yararlanılmıştır. $\mathrm{Bu}$ doğrultuda işgörenlerin sınırsız evren $(\mathrm{N}>10.000)$ olduğu belirlenmiştir. Sınırsız evrenlerin örneklem hesaplamasında Ural ve Kılıç (2013)'a göre $n=\frac{1^{2} .1,96^{2}}{0,1^{2}}=384$ olmalıdır. Söz konusu evreni doğru verilerle analiz edebilmek ve doğru sonuçlara ulaşabilmek için seçilecek her şehir için en az 384 örneklem kapasitesine ulaşmak planlanmıştır. Araştırmada; hata payı, güvenirlik düzeyi ve geri dönmeyecek ya da eksik kodlama vb. gibi değerlendirmeye alınmayacak derecede eksik ve hatalı veriler içeren anketlerin olabileceği ve aynı zamanda araştırmacının hedef kitleye ulaşma olanakları da dikkate alınarak, örneklemin daha üst düzeyde evreni temsil edebilmesini sağlayabilmek için sınır değeri olan 384 sayısının üzerine çıkılmaya çalışılmıştır. $\mathrm{Bu}$ doğrultuda, Afyonkarahisar ilinde faaliyette bulunan beş yıldızlı otel işletmelerine 500 adet anket, Antalya ili Lara-Kundu bölgesinde faaliyette bulunan beş yıldızlı otel işletmelerine 500 adet anket çoğaltılıp dağıtılmıştır. Sonuç olarak otel işletmelerinden geri dönen anket sayısı 860 olup, bunların 51'i hatal1-eksik dolum sebebiyle araştırmaya dâhil edilmemiştir. Değerlendirmeye alınan anketlerin 450 tanesi Antalya ili Lara-Kundu bölgesinde faaliyette bulunan 9 beş yıldızlı otel işletmelerinden, 359 tanesi Afyonkarahisar il merkezinde faaliyette bulunan 7 adet beş yıldızlı otel işletmelerinden elde edilmiş ve toplamda 809 adet anket analiz işlemine dahil edilmiştir. Araştırmada kullanılan ölçeklere ilişkin "Afyon Kocatepe Üniversitesi Bilimsel Araştırma ve Yayın Etiği Kurulu Başkanlığı'ndan” gerekli izin/onam alındıktan sonra ölçekler katılımcılara uygulanmıştır. (Karar No:2016/10)

Araştırmada otel çalışanlarının demografik ve bazı bireysel özelliklerine göre dağılımı frekans ve yüzde yöntemi ile verilmiştir. Ayrıca buna ilave olarak kullanılan ölçeğin güvenirlik analizinin tespitinde ise Cronbach's Alpha katsayısından faydalanılmıştır. Daha sonra ise yöneticilerin kullandıkları güç kaynakları ile işgörenlerin örgütsel özdeşleşmeye yönelik görüşlerinin frekans ve yüzde dağılımın yanı sıra, aritmetik ortalama ve standart sapma değerleri hesaplanarak betimlenmiştir. Yöneticilerin kullandıkları güç kaynaklarının işgörenlerin örgütsel özdeşleşme düzeyleri ile arasındaki ilişkiler/etkiler korelasyon ve regresyon analizi ile tespit edilmiştir. Korelasyon analizi sonucunda elde edilen katsayısının yorumlanmasında korelasyon katsayısının 0-0,29 arasında olması durumunda zayıf veya düşük, 0,30-0,64 arasinda olmas1 durumunda orta; 0,65-0,84 arasinda olmas1 durumunda kuvvetli/yüksek ve 0,85-1 arasında olması durumunda ise çok kuvvetli/çok yüksek düzeyde ilişki şeklinde (belirtilen aralıklarla ilgili kesin sınırlar olmamakla birlikte) niteleme yapılmıştır (Ural ve Kıliç, 2013). Diğer taraftan değişkenler arasındaki neden-sonuç ilişkisini (güç kaynaklarının işgörenlerin örgütsel özdeşleşme ve yabancılaşma düzeyleri üzerindeki etkisi) belirlemek için ise basit ve çoklu doğrusal regresyon modelleri oluşturulmuştur. Bu kapsamda çalışmanın izleyen kısmında verilerin analizi doğrultusunda elde edilen bulgulara yer verilmiştir. 


\section{Bulgular}

Tablo 1'e göre araştırmaya katılan işgörenlerin \%55,6's1 Antalya, \%44,4'ü Afyonkarahisar ilinde çalışmaktadır. Araştırmaya katılan işgörenlerin \%50,2'si kadın, \%49,8 erkek işgörenlerden oluşmaktadır. Katılımcıların medeni durumları incelendiğinde \%55,7'si bekar, \%44,3'ü evli olduğu görülmektedir. Araştırmaya katılan işgörenlerin yaş grupları incelendiğinde 20 yaş ve/veya altı \%8,4, 21-28 yaş aras1 \%34,7, 29-36 yaş arası \%30,5, 37-44 yaş aras1 \%19,2, 45-52 yaş aras1 \%7,2 olarak bulgulandığ 1 görülmektedir. Araştırmaya katılan işgörenlerin eğitim durumları sırasıyla ilköğretim \%9, ortaöğretim (Lise) $\% 26,5$, önlisans $\% 26$, lisans $\% 22,7$, lisansüstü \%15,8 biçimindedir.

Ankete katılan işgörenlerin çalıştıkları departmanlar incelendiğinde önbüro \%18,7, yiyecek içecek \%23,9, kat hizmetleri \%15,6, insan kaynakları \%13, halkla ilişkiler \%9, satış pazarlama \%12,2, diğer \%7,7 olarak belirlenmiştir. İşgörenlerin sektörde çalışma süreleri ise 1 y1l ve/veya daha az \%13,3, 2-4 y1 \%29,8, 5-7 y1l \%23,6, 8-10 y1l \%20,8, 11 y1l ve/veya daha fazla \%12,5 olarak görülmektedir. Otel işletmelerinde çalışan işgörenlerin gelir durumları incelendiğinde ise $1300 \mathrm{TL}$ ve/veya daha az \%16,6, 1301-1900 TL aras1 \%38,1, 1901-2500 TL aras1 \%25,8, 2501-3100 TL aras1 \%15, $3101 \mathrm{TL}$ ve/veya üstü \%4,6 olarak tespit edilmiştir.

Tablo 1. Katılımcıların bireysel özelliklerine ilişkin bulgular (n: 809)

\begin{tabular}{|c|c|c|c|c|c|c|c|}
\hline \multicolumn{2}{|c|}{ Bireysel Değişkenler } & $\mathrm{f}$ & $\%$ & \multicolumn{2}{|r|}{ Bireysel Değişkenler } & $\mathrm{f}$ & $\%$ \\
\hline \multirow{5}{*}{ Gelir } & $\begin{array}{l}1300 \text { TL ve/veya daha } \\
\text { az }\end{array}$ & 134 & 16,6 & \multirow{6}{*}{$\begin{array}{l}\text { Eğitim } \\
\text { Durumu }\end{array}$} & İlköğretim & 73 & 9,0 \\
\hline & $1301-1900 \mathrm{TL}$ & 308 & 38,1 & & Ortaöğretim (Lise) & 214 & 26,5 \\
\hline & $1901-2500 \mathrm{TL}$ & 209 & 25,8 & & Ön Lisans & 210 & 26,0 \\
\hline & $2501-3100 \mathrm{TL}$ & 121 & 15,0 & & & & \\
\hline & 3101 TL ve üstü & 37 & 4,6 & & Lisans & 184 & 22,1 \\
\hline \multirow{6}{*}{ Yaş } & 20 yaş ve/veya altı & 68 & 8,4 & & Lisansüstü & 128 & 15,8 \\
\hline & $21-28$ yaş arası & 281 & 34,7 & \multirow{5}{*}{$\begin{array}{l}\text { Sektörde } \\
\text { Çalışma } \\
\text { Süresi }\end{array}$} & 1 Yil ve/veya daha az & 108 & 13,3 \\
\hline & $29-36$ yaş arası & 247 & 30,5 & & $2-4 Y_{11}$ & 241 & 29,8 \\
\hline & $37-44$ yaş aras1 & 155 & 19,2 & & $5-7 Y_{11}$ & 191 & 23,6 \\
\hline & \multirow{2}{*}{$45-52$ yaş arası } & \multirow{2}{*}{58} & \multirow{2}{*}{7,2} & & $8-10 Y_{11}$ & 168 & 20,8 \\
\hline & & & & & 11 Y1l ve/veya daha fazla & 101 & 12,5 \\
\hline \multirow{2}{*}{$\begin{array}{l}\text { Medeni } \\
\text { Durum }\end{array}$} & Bekâr & 451 & 55,7 & \multirow{5}{*}{$\begin{array}{l}\text { İşletmede } \\
\text { Çalişma } \\
\text { Süresi }\end{array}$} & 1 Yil ve/veya daha az & 107 & 13,2 \\
\hline & Evli & 358 & 44,3 & & $2-4 Y_{11}$ & 279 & 34,5 \\
\hline \multirow{7}{*}{ Departman } & Önbüro & 151 & 18,7 & & $5-7 Y_{11}$ & 218 & 26,5 \\
\hline & Yiyecek İçecek & 193 & 23,9 & & $8-10 Y_{11}$ & 129 & 15,9 \\
\hline & Kat Hizmetleri & 126 & 15,6 & & 11 Y1l ve/veya daha fazla & 76 & 9,4 \\
\hline & İnsan Kaynakları & 105 & 13,0 & \multirow{6}{*}{$\begin{array}{l}\text { İşletmenin } \\
\text { Bulunduğu } \\
\text { İl }\end{array}$} & \multirow{4}{*}{ Antalya } & \multirow{4}{*}{450} & \multirow{4}{*}{55,6} \\
\hline & Halkla İlişkiler & 73 & 9,0 & & & & \\
\hline & Satış Pazarlama & 99 & 12,2 & & & & \\
\hline & Diğer & 62 & 7,7 & & & & \\
\hline \multirow{2}{*}{ Cinsiyet } & Kadın & 406 & 50,2 & & \multirow{2}{*}{ Afyonkarahisar } & \multirow{2}{*}{359} & \multirow{2}{*}{44,4} \\
\hline & Erkek & 409 & 49,8 & & & & \\
\hline
\end{tabular}

Araştırmada kullanılan kullanılan ölçeklere ilişkin güvenirlik analizleri (Cronbach's Alpha) sonuçları Tablo 2'de sunulmuştur.

Tablo 2. Güç kaynakları, örgütsel özdeşleşme ölçeklerine ilişkin cronbach's alpha katsayıları

\begin{tabular}{llcc}
\hline Ölçekler & Alt Ölçekler (Boyutlar) & Madde Sayıs1 & Cronbach's Alpha \\
\hline & Uzmanlık Gücü & 7 & 0,736 \\
\cline { 2 - 4 } Güç Kaynakları & Beğiye Dayalı Güç & 7 & 0,784 \\
\cline { 2 - 4 } & Ödüllendirici Güç & 7 & 0,801 \\
\cline { 2 - 4 } & Zorlayıcı Güç & 7 & 0,756 \\
\cline { 2 - 4 } & Yasal Güç & 7 & 0,767 \\
\hline Özdeşleşme & & 6 & 0,799 \\
\hline
\end{tabular}

Tablo 2'ye göre güç kaynakları ölçeğine ilişkin Cronbach's Alpha katsayıları incelendiğinde; uzmanlık gücü için Cronbah's Alpha değeri 0,736, beğeniye dayalı güç 
Cronbach's Alpha değeri 0,784, ödüllendirici güç için Cronbach's Alpha değeri 0,801, zorlayıc1 güç için Cronbach's Alpha değeri, 0,756, yasal güç için Cronbach's Alpha değeri 0,767 olarak hesaplanmıştır. Örgütsel özdeşleşme ölçeği için hesaplanan Cronbach's Alpha değeri ise 0,799 olduğu görülmektedir. Elde edilen bu verilen doğrultusunda çalışmada kullanılan ölçeklere ait güvenirlik düzeyinin yüksek olduğu söylenebilir. Bunlara ek olarak her bir ölçeğin Cronbach's Alpha değerlerinin 0,70 değerinin üzerinde olduğu görülmektedir. Bu değerler ölçeklerin iç tutarlık düzeylerinin yeterli olduğunu göstermektedir.

Tablo 3'de araştırmaya katılan otel işletmeleri işgörenlerinin yöneticilerinin kullandıkları güç kaynaklarına ilişkin algılamalarının yüzde, frekans, aritmetik ortalama ve standart sapma değerlerine yer verilmiştir. Güç kaynakları ölçeği uzmanlık gücü alt boyutu aritmetik ortalamas $\bar{X}=2,94$ olarak elde edilmiştir. İlgili ölçekte; "yönetimde uzmanlığa sahip olduğu için üstüm bana stratejiler ya da politikalarla ilgili nasihatlar verebilir" ifadesi incelendiğinde otel işgörenleri \%14,2 "hiç katılmıyorum", \%29,2 "az katılıyorum", \%24 "orta düzeyde katılıyorum", \%17,8 "çok katılıyorum", \%14,8 "tamamen katıliyorum" biçiminde görüş belirtmişlerdir. İlgili madde uzmanlık gücü alt boyutunda diğer maddelere oranla düşük bir ortalama değerine $(\overline{\mathrm{X}}=2,90)$ sahiptir. Bu veriler doğrultusunda otel işgörenleri yöneticilerinin vereceği nasihatlara olumsuz baktıkları ifade edilebilir. $\mathrm{Bu}$ maddede göze çarpan değer katılımcıların \%29,2 oranında az katılıyorum biçiminde yanıt vermeleridir. Otel işgörenlerinin büyük bir çoğunluğu üstlerinden gelecek stratejik tavsiyelere karşı olumsuz görüş belirtmektedirler. Diğer yandan "üstümün iş ile ilgili problemlerdeki nasihatleri genellikle doğru olduğu için daima ona danışırım" ifadesine verilen yanıtlar incelendiğinde otel işgörenlerininin $\% 14,2$ "hiç katılmıyorum", \%29,5 "az kat1lıyorum", \%22,6 "orta düzeyde katıllyorum", \%19 "çok katılıyorum", \%14,6 "tamamen katılıyorum" biçiminde görüş belirttikleri ortaya çıkmıştır. $\mathrm{Bu}$ madde sonuçları otel işgörenlerinin yaklaşı \%45 oranında üstlerine danışmaya ilişkin olumsuz görüş belirttikleri gözlenmiştir. İlgili maddenin aritmetik ortalama değeri de diğer ifadelere oranla düşük $(\bar{X}=2,90)$ bir orana sahiptir. "Üstüm işimi yapabilmek için yardım ihtiyacı duyduğunda başvurulabilecek bir birey olup önemli oranda bir iş tecrübesine sahiptir" ifadesine bakıldığında \%12,7 "hiç katılmıyorum", \%29,3 "az katılıyorum", \%24,1 "orta düzeyde katıliyorum", \%19,5 "çok katıliyorum", \%14,3 "tamamen katıliyorum" sonuçları ortaya çıkmaktadır. Bu ifadenin aritmetik ortalama değeri $\overline{\mathrm{X}}=2,93$ olarak tespit edilmiş olup, diğer ifadelere oranla daha düşük bir değere sahip olduğu görülmektedir. "Konusunda uzman olduğu için üstümün bana önerdiklerini yapmayı tercih ederim" ifadesi katılımcılar tarafından $\% 12,1$ "hiç katılmıyorum", \%28,1 "az katılıyorum", \%25,7 "orta düzeyde katılıyorum”, \%18,3 "çok katılıyorum", \%15,8 "tamamen katılıyorum" olarak yanıtlanmıştır. Bu maddenin aritmetik ortalama değerine bakıldığında uzmanlık gücü alt boyutunun en yüksek değerine sahip $(\bar{X}=2,98)$ madde olduğu görülmektedir. "Üstüm kendi alanında eğitimli olup o konunun uzmanıdır" ifadesi ise araştırmaya katılan işgörenler tarafindan \%11,9 "hiç katılmıyorum", \%29,7 "az kat1lıyorum", \%23,7 "orta düzeyde kat1lıyorum", \%18,8 "çok katılıyorum", \%15,9 "tamamen katıllyorum" olarak belirlenmiştir. İlgili ifadenin aritmetik ortalama değeri diğer ifadelere göre daha yüksek $(\overline{\mathrm{X}}=2,97)$ bir değere sahip olduğu görülmektedir. "Zor bir iş ile karşılaşıldığı zaman üstüm onu tamamlayabilecek uzmanlı bilgisine sahiptir" ifadesinin yanttları incelendiğinde ise otel işgörenlerinin \%13,2 "hiç katılmıyorum", \%27,2 "az katılıyorum", \%24,2 "orta düzeyde katılıyorum", \%19,8 "çok katılıyorum”, \%15,6 "tamamen katılıyorum” olduğu görülmektedir. $\mathrm{Bu}$ maddenin aritmetik ortalama değeri diğer ifadelere oranla daha yüksek $(\overline{\mathrm{X}}=2,97)$ olarak tespit edilmiştir.

Araştırma sonucunda beğeniye dayalı güç kaynağ 1 aritmetik ortalama değeri $\overline{\mathrm{X}}=3,07$ olarak elde edilmiştir. Araştırmaya katılım sağlayan otel işgörenlerin beğeniye dayalı güç alt boyutunda verdikleri yanıtlar genel itibari ile orta düzeyde katılıyorum seçeneğine yakın ve üstü biçiminde olduğu görülmektedir. "Üstümün kişisel özelliklerinden hoşlanırım" ifadesine verilen yanıtlar incelendiğinde \%11,6 "hiç katılmıyorum", \%25,7 "az katılıyorum", \%24,1 "orta 
düzeyde katılıyorum", \%24,4 "çok kat1lyorum", \%14,2 "tamamen katılıyorum biçiminde olduğu görülmektedir. İlgili ifadenin aritmetik ortalama değeri ise diğer ifadelere oranla en düşük değere $(\bar{X}=3,04)$ sahip olarak belirtilmiştir. Bu veriler doğrultusunda Antalya ve Afyonkarahisar illerinde bulunan beş yıldızlı otel işletmelerinde çalışan işgörenler üstlerinin kişisel özelliklerinden orta düzeyde hoşlanmaktadırlar biçiminde yorumlanabilir. İlgili ölçekte "Her çalışana eşit davrandığ 1 için üstümü çok beğenirim" maddesi katılımcılar tarafından \%13,1 "hiç katılmıorum", \%23,9 "az kat1lyyorum", \%23,2 "orta düzeyde katılıyorum”, \%24,6 "çok katılıyorum", \%15,2 "tamamen katılıyorum" şeklinde yanıtlanmıştır. Bu maddenin aritmetik ortalama değeri incelendiğinde diğer maddelere oranla daha düşük bir ortalama ( $\bar{X}=3,05)$ değerine sahip olduğu görülmektedir. "Üstümün arkadaşı olmak istediğim için yaptığım işle onu mutlu etmek isterim" ifadesi katılımcılar tarafindan \%13,6 "hiç katılmıyorum", \%21,9 "az katıllyorum", \%22,1 "orta düzeyde katılıyorum", \%24,5 "çok katılıyorum”, \%17,9 "tamamen katılıyorum" şeklinde yanıtlanmıştır. İlgili madde diğer ifadeler arasında katılımcılar tarafından daha olumlu biçimde değerlendirilmiştir. Bu doğrultuda bu maddenin aritmetik ortalama değeri $(\bar{X}=3,11)$ en yüksek olarak elde edilmiştir. Otel işgörenleri üsteleriyle arkadaş olmak istedikleri için onları yaptıkları işle mutlu etmek istemektedirler. Araştırmada göze çarpan bir diğer madde ise "üstüm ile içtenlikle iyi, kişisel ilişkiler geliştirmek isterim" ifadesidir. Bu maddeye katılımcılar \%11,7 "hiç katılmıyorum", \%22,4 "az katılıyorum", \%26,2 "orta düzeyde katılıyorum", \%24,7 "çok katılıyorum", \%15 "tamamen katılıyorum" şeklinde yanıt vermişlerdir. İlgili madde diğer ifadeler ile kıyaslandığında daha yüksek bir aritmetik ortalama değerine $(\overline{\mathrm{X}}=3,09)$ sahip olarak bulunmuştur.

Ödüllendirici güç alt boyutu aritmetik ortalama değeri $\bar{X}=2,99$ olarak belirlenmiştir. Katılımcıların verdikleri cevaplar incelendiğinde araştırmada kullanılan ölçek değerlendirmesine göre orta düzeyde katılıyorum seçeneğine yakın görüş belirttikleri görülmektedir. Katılımcıların verdikleri yanıtlar incelendiğinde "eğer iş performansım sürekli olarak ortalamanın üzerindeyse üstüm benim terfimi önerebilir" ifadesinin en düşük olduğu aritmetik ortalama değerine $(\bar{X}=2,93)$ sahip olduğu görülmektedir. İlgili ifade katılımcılar tarafından \%12,4 "hiç katılmıyorum", \%30,2 "az katılıyorum", \%23,6 "orta düzeyde katılıyorum", \%20,1 "çok katılıyorum", \%13,7 "tamamen katılıyorum” şeklinde yanıtlanmıştır. Ödüllendirici güç alt boyutunda düşük aritmetik ortalamaya sahip bir diğer ifade ise "üstüm performans değerlendirilmesinde bana olumlu katkılar sağlayabilecek ödüller verebilir" maddesi olarak bulgulanmıştır. İlgili ifade diğer ifadelere oranla daha düşük bir aritmetik ortalama değerine ( $\overline{\mathrm{X}}=2,95)$ sahiptir. Bu madde katılımcılar tarafından \%12,5 "hiç katılmıyorum", \%27,9 "az katılıyorum", \%25,5 "orta düzeyde katılıyorum", \%19,9 "çok katılıyorum", \%14,2 "tamamen katılıyorum" biçiminde yanıtlanmıştır. Söz konusu madde katılımcılar tarafindan diğer ifadelere oranla daha olumsuz olarak değerlendirilmiştir. "İş performansım çok iyiyse üstüm benim için ücret artışı önerebilir" ifadesinin diğer ifadelere oranla daha yüksek aritmetik ortalama değerine $(\overline{\mathrm{X}}=3,06)$ sahip olduğu görülmektedir. Bu ifadeye katılımcılar \%12 "hiç katılmıyorum", \%25,6 "az katılıyorum", \%23,7 "orta düzeyde katılıyorum", \%21,4 "çok katılıyorum", \%17,3 "tamamen katılıyorum" olarak değerlendirmişlerdir. Tablo'ya göre diğer ifadelere oranla daha yüksek bir aritmetik ortalama değerine $(\bar{X}=3,06)$ sahip olan madde "eğer yaptığım işin kalitesi özellikle iyi ise üstüm bunu kendi amirine duyurabilir" maddesidir. İlgili maddeye katılımcılar \%11,7 "hiç katılmıyorum", \%27,3 "az katılıyorum", \%21,5 "orta düzeyde kat1lıyorum", \%22,2 "çok katılıyorum", \%17,2 "tamamen katılıyorum" olarak yanıt vermişlerdir. $\mathrm{Bu}$ madde diğer maddeler ile karşılaştıııldığında katılımcılar tarafindan daha olumlu değerlendirildiği söylenebilir. "Yaptığım işler çok iyi ise üstüm benim yükselmem için firsatlar yaratabilir" ifadesi katılımcılar tarafından \%13 "hiç katılmıyorum", \%26,1 "az kat1lyorum", \%22,4 "orta düzeyde katılıyorum", \%22,7 "çok katılıyorum", \%15,8 "tamamen katılıyorum" biçiminde yanıtlanmıştır. İlgili maddenin aritmetik ortalama değeri ise $\bar{X}=3,02$ olarak tespit edilmiştir. 
Tablo 3. Güç kaynakları ölçeğine ilişkin betimsel istatistikler

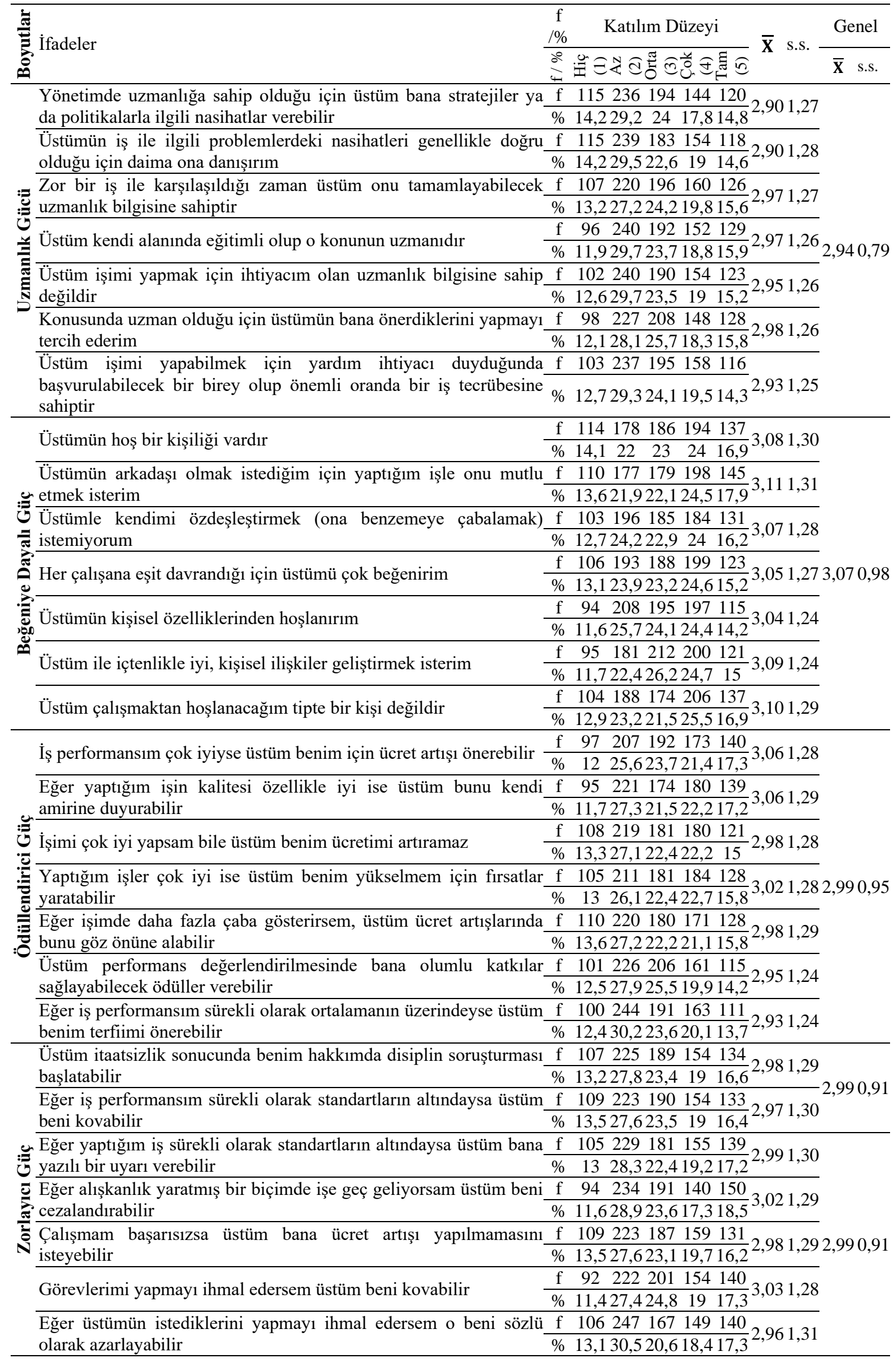


Pelit ve Karaçor/Yöneticilerinin Kullandıkları Güç Kaynaklarının İşgörenlerin Örgütsel Özdeşleşme Düzeylerine

Etkisi: Beş Yıldızlı Otel İşletmelerinde Bir Araştırma/The Effect of Power Sources Used by Hotel Managers on Organizational Identification: A Study on Five Star Hotels

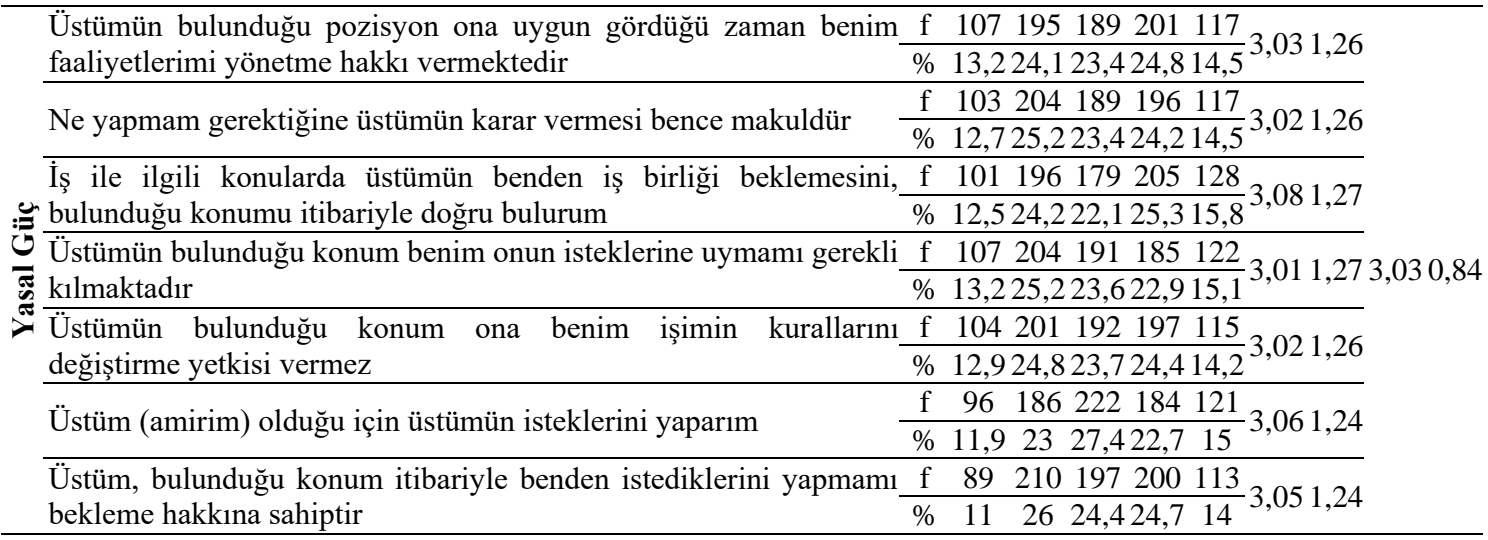

Zorlayıcı güç alt boyutunun genel aritmetik ortalama değeri $\bar{X}=2,99$ olarak tespit edilmiştir. Katılımcılar zorlayıcı güç alt boyutuna genel olarak orta düzeyde katılıyorum seçeneğine yakın cevap vermişlerdir. "Eğer üstümün istediklerini yapmayı ihmal edersem o beni sözlü olarak azarlayabilir" ifadesi diğer ifadeler arasında en düşük aritmetik ortalamaya $(\overline{\mathrm{X}}=2,96)$ sahip olarak belirlenmiştir. İfadeye verilen yanıtlar ise \%13,1 "hiç katılmıyorum", \%30,5 “az katıliyorum”, \%20,6 "orta düzeyde kat1lıyorum”, \%18,4 "çok katıllyorum”, \%17,3 "tamamen katılıyorum" biçimindedir. "Ĕğer iş performansım sürekli olarak standartların altındaysa üstüm beni kovabilir" ifadesi ise zorlayıcı güç alt boyutunun düşük aritmetik ortalamaya $(\overline{\mathrm{X}}=2,97)$ sahip diğer maddesidir. $\mathrm{Bu}$ ifade katılımcılar tarafından \%13,5 "hiç kat1lmıyorum", \%27,6 "az kat1liyorum”, \%23,5 "orta düzeyde kat1liyorum”, \%19 "çok katılıyorum", \%16,4 "tamamen katılıyorum" şeklinde yanıtlanmıştır. "Görevlerimi yapmayı ihmal edersem üstüm beni kovabilir" ifadesi katılımcılar tarafından \%11,4 "hiç katılmıyorum", \%27,4 "az katılıyorum", \%24,8 "orta düzeyde katılıyorum", \%19 "çok katılıyorum", \%17,3 "tamamen katılıyorum" biçiminde yanıtlanmıştır. İlgili ifade diğer ifadeler ile kıyaslandığında en yüksek aritmetik ortalamaya $(\bar{X}=3,03)$ sahip olduğu görülmektedir. Bu ifade katılımcılar tarafından daha olumlu olarak değerlendirilmiştir. "Eğer alışkanlık yaratmış bir biçimde işe geç geliyorsam üstüm beni cezalandırabilir" ifadesi katılımcılar tarafından \%11,6 "hiç katılmıyorum", \%28,9 "az kat1lıyorum", \%23,6 "orta düzeyde katıliyorum”, \%17,3 "çok katılıyorum", \%18,5 "tamamen katılıyorum" biçiminde gerçekleşmiştir. Bu ifadenin diğer ifadelere oranla daha yüksek bir aritmetik ortalamaya $(\overline{\mathrm{X}}=3,02)$ sahip olduğu görülmektedir.

Ölçekte, yasal güç alt boyutu genel aritmetik ortalama değeri $\bar{X}=3,03$ olarak tespit edilmiştir. "Üstümün bulunduğu konum benim onun isteklerine uymamı gerekli kılmaktadır" ifadesi katılımcılar tarafindan \%13,2 "hiç katılmıyorum", \%25,2 "az katılıyorum", \%23,6 "orta düzeyde katılıyorum", \%22,9 "çok katılıyorum", \%15,1 "tamamen katıllyorum" biçiminde cevaplandırılmıştır. Bu ifade sahip olduğu aritmetik ortalama değeri ile $(\overline{\mathrm{X}}=3,01)$, katılımcılar tarafindan en olumsuz değerlendirilen madde olmuştur. Öte yandan "Ne yapmam gerektiğine üstümün karar vermesi bence makuldür" ifadesine katılımcılar \%12,7 "hiç katılmıyorum", \%25,2 "az katılıyorum", \%23,4 "orta düzeyde katılıyorum", \%24,2 "çok katılıyorum”, \%14,5 "tamamen katılıyorum" şeklinde yanıt vermişlerdir. Bu ifadenin aritmetik ortalama değeri ise $\overline{\mathrm{X}}=3,02$ olarak tespit edilmiştir. Söz konusu madde diğer ifadelere oranla katılımcılar tarafından daha olumsuz değerlendirilmiştir. "İş ile ilgili konularda üstümün benden iş birliği beklemesini, bulunduğu konumu itibariyle doğru bulurum" ifadesi katılımcılar tarafindan \%12,5 "hiç katılmıyorum", \%24,2 "az katılıyorum", \%22,1 "orta düzeyde katılıyorum”, \%25,3 "çok katılıyorum", \%15,8 "tamamen katılıyorum" biçiminde yanıtlanmıştır. İlgili ifadenin aritmetik ortalama değeri diğer ifadelere oranla en yüksek değere $(\overline{\mathrm{X}}=3,08)$ sahip olarak elde edilmiştir. $\mathrm{Bu}$ ifade katılımcılar tarafindan diğer ifadelere oranla daha olumlu olarak değerlendirilmiștir.Tabloda göze çarpan bir diğer sonuç ise "üstüm (amirim) olduğu için üstümün isteklerini yaparım" ifadesine verilen yanıtlardır. Bu ifade katılımcılar tarafından 
\%11,9 "hiç katılmıyorum", \%23 "az kat1lyyorum", \%27,4 "orta düzeyde katılıyorum”, \%22,7 "çok katılıyorum", \%15 "tamamen katılıyorum" biçimindedir. Bu ifade diğer ifadelere oranla daha yüksek bir aritmetik ortalama değerine $(\bar{X}=3,06)$ sahiptir. İlgili ifade otel işgörenleri tarafından daha olumlu olarak değerlendirilmiştir.

Katılımcıların güç kaynakları ölçeğine verdikleri yanıtlar genel olarak değerlendirildiğinde otel işgörenlerinin yanttları genel itibariyle orta düzeyde katıliyorum biçiminde gerçekleşmiştir.Otel işgörenleri yöneticilerinin en çok beğeniye dayalı güç kaynağını kullandıklarını ifade etmişlerdir. Beğeniye dayalı güç kaynağının sahip olduğu aritmetik ortalama değeri $(\overline{\mathrm{X}}=3,07)$ diğer alt boyutlar arasında en yüksek değere sahiptir. Otel işgörenlerinin verdikleri yanıtlar doğrultusunda yöneticiler tarafindan en az kullanılan güç kaynağ 1 ise uzmanlık gücü olarak tespit edilmiştir. Bu doğrultuda otel yöneticilerinin uzmanlık gücünün az kullanmaları işinde uzman ve işi bilen bireylerin daha az olduğu yönünde yorumlanabilir. Öte taraftan en çok kullanılan güç kaynağının beğeniye dayalı güç olması otel yöneticilerinin işgörenler tarafından beğenilerek ve verdiği emirlerin, isteklerin herhangi bir statü, zorunluluk gibi durumlar söz konusu olmadan yerine getirilmesi yönünde avantaj sağlar. Ancak uzmanlık güç kaynağı açılımı incelendiğinde yöneticinin alanında uzmanlık gerektiren bilgilere sahip olduğu ve astlarını mantıklı argümanlar sunarak ikna etme gücüne sahip olduğu görülmektedir. Uzmanlık gücünün otel işletmelerinde diğer güç kaynaklarına göre daha az kullanılması yöneticinin alanında uzmanlık gerektiren ikna edici güce daha az sahip olduğunu göstermektedir. $\mathrm{Bu}$ doğrultuda uzmanlık gücünün az kullanılması otel işletmeleri açısından olumsuz bir durum olarak değerlendirilebilir. Diğer taraftan beğeniye dayalı güç yöneticinin sahip olduğu karizmatik liderlik gücünü ifade eder. Bu güç kaynağında işgörenler yöneticilerini bir lider gibi görüp, onun isteklerini yerine getirirler ve yöneticilerine destekleyici bir unsur olmadan saygı duyarlar. Bu durumda işgören yöneticisini bir lider gibi görmektedir. Bu durum otel işletmeleri için olumlu olarak ifade edilebilir. Çünkü astlar üstlerini bir liderlik vasfiyla görmekte ona saygı duymaktadırlar. Ancak otel işletmelerinde en yaygın güç kaynağ 1 olarak tespit edilen beğeniye dayalı güç kaynağı liderin sahip olduğu bireysel özellikleri ifade etmektedir. Otel yöneticilerinin uzmanlık gücünü daha fazla kullanmaları gerekmektedir. Çünkü mantıklı ve geçerli veriler ikna gücünü ve alanında uzmanlık bilgisini içeren uzmanlık gücü otel yönetiminde yöneticinin kabul edilirlik düzeyine olumlu etki edecektir. Çalışmanın ilerleyen kısmında örgütsel özdeşleşme ölçeğine ilişkin betimsel istatistikler verilmiştir. Tablo 4'de araştırmaya katılan otel işletmeleri işgörenlerinin örgütsel özdeşleşme düzeylerine ilişkin görüşlerinin yüzde, frekans, aritmetik ortalama ve standart sapma değerlerine yer verilmiştir.

Anket uygulanan beş y1ldızlı otel işletmelerinde çalışan işgörenlerin örgütsel özdeşleşme ölçeğine ilişkin verdikleri cevaplar incelendiğinde araştırmada kullanılan ölçek derecelendirmesine göre orta düzeyde katılıyorum biçiminde görüş bildirdikleri görülmektedir (Tablo 4). Söz konusu örgütsel özdeşleşme ölçeğine ilişkin aritmetik ortalama değeri $\bar{X}=3,05$ olarak tespit edilmiş olup katılımcı cevaplarının orta düzeyde katılıyorum ifadesinde yoğunlaştığını göstermektedir. "Çalıştığım işletmeyle ilgili konuşurken, genellikle "onlar" yerine "biz" derim" ifadesi katılımcılar tarafından \%13,8 "hiç katılmıyorum", \%20,3 "az kat1liyorum", \%22,6 "orta düzeyde katılıyorum", \%27,7 "çok katıllyorum”, \%15,6 "tamamen katılıyorum" olarak belirtilmiştir. İlgili maddenin aritmetik ortalama değeri $\overline{\mathrm{X}}=3,11$ olarak tespit edilmiş olup diğer ifadelere oranla daha yüksek bir değere sahip olduğu görülmektedir. Bir diğer ifade olan "çalıştığım işletmenin başarıları benim başarılarımdır" ifadesi katılımcılar tarafından $\% 13,7$ "hiç katılmıyorum", \%19,2 "az katılıyorum”, \%24,2 "orta düzeyde katılıyorum”, \%27,8 "çok katılıyorum", \%15,6 "tamamen katılıyorum” biçimindedir. Bu ifade örgütsel özdeşleşme ölçeğinde diğer ifadelere oranla daha yüksek $(\bar{X}=3,11)$ bir aritmetik değere sahiptir. "Birisi çalıştı̆̆ım işletmeyi övdüğünde, bunu kişisel bir iltifat olarak hissederim" ifadesine katılımcılar $\% 15,2$ "hiç katılmıyorum", \%20,5 "az katılıyorum", \%24,5 "orta düzeyde katılıyorum”, \%26,7 "çok katılıyorum", \%13,2 "tamamen katıllyorum" olarak görüş belirtmişlerdir. Bu ifadenin aritmetik değeri incelendiğinde diğer maddelere oranla en düşük aritmetik ortalama değerine 
$(\overline{\mathrm{X}}=3,02)$ sahip olduğu gözlenmiştir. Örgütsel özdeşleşme ölçeği ifadelerinden "birisi benim çalıştığım işletmeyi eleştirdiğinde, bunu kişisel bir hakaret gibi hissederim" ifadesine işgörenler \%14,8 "hiç katılmıyorum", \%22,2 "az katılıyorum", \%22 "orta düzeyde katılıyorum", \%26,8 "çok katılıyorum", \%14,1 "tamamen katılıyorum" biçiminde yanıtlamışlardır. Söz konusu maddenin aritmetik değeri diğer ifadelere oranla daha düşük bir değere $(\overline{\mathrm{X}}=3,03)$ sahiptir. $\mathrm{Bu}$ doğrultuda araştırma konusu olan örgütsel özdeşleşme ölçeğine dair işgörenlerin verdikleri yanıtlar genel itibari ile orta düzeyde katılıyorum maddesinde yoğunlaşmıştır.

Tablo 4. Örgütsel özdeşleşme ölçeğine ilişkin betimsel istatistikler

\begin{tabular}{|c|c|c|c|c|c|c|c|c|}
\hline \multirow[b]{2}{*}{ İfadeler } & \multicolumn{5}{|c|}{ Katılım Düzeyi } & \multirow[b]{2}{*}{ 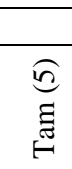 } & \multirow[b]{2}{*}{$\overline{\mathbf{X}}$} & \multirow[b]{2}{*}{ s.s. } \\
\hline & $\stackrel{8}{i}$ & 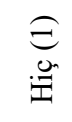 & $\begin{array}{l}\overparen{d} \\
\frac{N}{4}\end{array}$ & $\begin{array}{l}\widehat{0} \\
\frac{\pi}{0} \\
0\end{array}$ & $\frac{\overparen{J}}{\frac{y}{0}}$ & & & \\
\hline \multirow{2}{*}{$\begin{array}{l}\text { Birisi benim çalıştığım işletmeyi eleştirdiğinde, bunu kişisel } \\
\text { bir hakaret gibi hissederim }\end{array}$} & & 120 & 180 & 178 & 217 & 114 & \multirow{2}{*}{3,03} & \multirow{2}{*}{1,28} \\
\hline & $\%$ & 14,8 & 22,2 & 22 & 26,8 & 14,1 & & \\
\hline \multirow{2}{*}{\multicolumn{2}{|c|}{$\begin{array}{lllll}\begin{array}{l}\text { Başkalarının } \\
\text { ilgiliyimdir }\end{array} & \text { çalıştığım işletmeyle ilgili düşünceleriyle } \frac{f}{\%} \\
\end{array}$}} & 128 & 164 & 171 & 227 & 119 & \multirow{2}{*}{$-3,06$} & \multirow{2}{*}{1,31} \\
\hline & & 15,8 & 20,3 & 21,1 & 28,1 & 14,7 & & \\
\hline \multirow{2}{*}{$\begin{array}{l}\text { Çalıştığım işletmeyle ilgili konuşurken, genellikle "onlar" } \\
\text { yerine "biz" derim }\end{array}$} & & 112 & 164 & 183 & 224 & 126 & \multirow{2}{*}{$-3,11$} & \multirow{2}{*}{1,28} \\
\hline & $\%$ & 13,8 & 20,3 & 22,6 & 27,7 & 15,6 & & \\
\hline \multirow{2}{*}{ Çalıştığım işletmenin başarıları benim başarılarımdır } & $\mathrm{f}$ & 111 & 155 & 196 & 225 & 122 & \multirow{2}{*}{$-3,11$} & \multirow{2}{*}{1,27} \\
\hline & $\%$ & 13,7 & 19,2 & 24,2 & 27,8 & 15,1 & & \\
\hline \multirow{2}{*}{$\begin{array}{l}\text { Birisi çalıştığım işletmeyi övdüğünde, bunu kişisel bir iltifat } \mathrm{f} \\
\text { olarak hissederim }\end{array}$} & & 123 & 166 & 197 & 216 & 107 & \multirow{2}{*}{$-3,02$} & \multirow{2}{*}{1,27} \\
\hline & $\%$ & 15,2 & 20,5 & 24,4 & 26,7 & 13,2 & & \\
\hline \multirow{2}{*}{\multicolumn{2}{|c|}{$\begin{array}{l}\text { Eğer medyadaki bir haber çalıştı̆̆ım işletmeyi eleştirse, utanç } \frac{f}{\%} \\
\text { duyarım }\end{array}$}} & 125 & 179 & 179 & 201 & 125 & \multirow{2}{*}{$-3,03$} & \multirow{2}{*}{1,31} \\
\hline & $\%$ & 15,5 & 22,1 & 22,1 & 24,8 & 15,5 & & \\
\hline Genel & & & & & & & 3,05 & 0,90 \\
\hline
\end{tabular}

Araştırmaya katılan otel işgörenlerinin örgütsel özdeşleşme ve güç kaynakları alt boyutları konularına ilişkin görüşlerinin işletmenin faaliyet gösterdiği ile göre karşılaştırmasına yönelik t testi sonuçlarına gore, güç kaynakları alt boyutları arasında olan uzmanlık gücünde işletmenin faaliyet gösterdiği ile göre anlamlı bir farklılık tespit edilmiştir $(\mathrm{p}<0,05)$. Elde edilen bulgulara göre Afyonkarahisar ilinde çalışan otel yöneticileri $(\bar{X}=3,00)$ Antalya ilinde çalışan otel yöneticilerine $(\bar{X}=2,89)$ göre daha fazla uzmanlık gücünü kullanmaktadırlar. Öte yandan işgörenlerin örgütsel özdeşleşme düzeyleri ve yöneticilerinin kullandıkları güç kaynaklarının diğer alt boyutları ile işletmenin faaliyet gösterdiği ile göre karşılaştırılmasında söz konusu değişkenlerin otelin faaliyette bulunduğu ile göre anlamlı bir farklılık göstermediği tespit edilememiştir ( $\mathrm{p}>0,005)$.

Tablo 5. Güç kaynakları ile örgütsel özdeşleşme arasındaki ilişkiye yönelik korelasyon katsay1lar1-matrisi

\begin{tabular}{|c|c|c|}
\hline & Değişkenler & Özdeşleşme \\
\hline \multirow{5}{*}{ 湑 } & Uzmanlık Gücü & $0,237^{*}$ \\
\hline & Beğeniye Dayalı Güç & $0,304 *$ \\
\hline & Ödüllendirici Güç & $0,287^{*}$ \\
\hline & Zorlayıcı Güç & $-0,213^{*}$ \\
\hline & Yasal Güç & $-0,09 *$ \\
\hline
\end{tabular}

Tablo 5'de yöneticilerin kullandıkları güç kaynakları ile örgütsel özdeşleşme ilişkisini belirlemeye yönelik uygulanan Pearson Korelasyon analizi sonuçları sunulmuştur. Tablo 5 'deki bulgulara göre, yöneticilerin kullandıkları güç kaynakları ile örgütsel özdeşleşme arasındaki korelasyon katsayılarının tamamı anlamlı bulunmuştur $(\mathrm{p}<0,01)$. Otel yöneticilerinin kullandıkları güç kaynaklarının işgörenlerin örgütsel özdeşleşme düzeylerine etkisinin anlaşılabilmesi için çok değişkenli doğrusal regresyon analizi sonuçları ise Tablo 6'da sunulmuştur. 
Tablo 6'daki bulgulara göre, değişkenler arasındaki doğrusal regresyon modelinin anlamlı olduğu tespit edilmiştir $(\mathrm{F}=18,379 ; \mathrm{p}<0,01)$. Buna göre regresyon modeli şu şekilde kurulabilir: $\ddot{O} \ddot{O}=1,902+0,115 U G+0,203 B D G+0,174 \ddot{O} G-0,084 Z G+\mathcal{E}$

Kurulan söz konusu bu model yöneticilerin kullandıkları uzmanlık gücündeki 1 birimlik artışın, örgütsel özdeşleşmede 0,115 değerinde bir artışa neden olduğu görülmektedir. Bir diğer ifade ile yöneticilerin uzmanlık güç kaynağını tercih etmeleri, işgörenlerin örgütsel özdeşleşmelerini olumlu yönde etkilemektedir. Öte yandan araştırma sonucunda elde edilen bulgulara göre yöneticilerin kullandıkları beğeniye dayalı güç kaynağındaki 1 birimlik artış, örgütsel özdeşleşme üzerinde 0,203 değerinde bir artışa sebep olmaktadır. Bu doğrultuda yöneticilerin beğeniye dayalı güç kaynağını tercih etmeleri, işgörenlerin örgütsel özdeşleşme düzeylerine olumlu etki etmektedir.

Tablo 6. Güç kaynakları ile örgütsel özdeşleşme arasındaki ilişkiye ait çok değişkenli doğrusal regresyon analizi sonuçları

\begin{tabular}{|c|c|c|c|c|c|}
\hline Bağımsız Değişken & $b_{j}$ & $\mathrm{~S}\left(\mathrm{~b}_{\mathrm{j})}\right.$ & $\mathrm{T}$ & $\mathrm{p}$ & ANOVA \\
\hline Sabit & 1,902 & 0,312 & 6,087 & $0,000^{*}$ & \multirow{6}{*}{$\begin{array}{l}\mathrm{F}=18,379 \\
\mathrm{P}=0,000^{*}\end{array}$} \\
\hline Uzmanlık Gücü & 0,115 & 0,056 & 2,075 & $0,039 *$ & \\
\hline Beğeniye Dayalı Güç & 0,203 & 0,043 & 4,719 & $0,000 *$ & \\
\hline Ödüllendirici Güç & 0,174 & 0,043 & 4,067 & $0,000^{*}$ & \\
\hline Zorlayıcı Güç & $-0,084$ & 0,046 & $-1,929$ & $0,047 *$ & \\
\hline Yasal Güç & $-0,033$ & 0,050 & $-0,674$ & 0,500 & \\
\hline
\end{tabular}

Tablo 6 incelendiğinde yöneticilerin kullandıkları ödüllendirici güç kaynağında 1 birimlik artışın, örgütsel özdeşleşme üzerinde 0,174 birimlik bir artş̧a sebep olduğu görülmektedir. Burada dikkat edilmesi gereken nokta ise yöneticilerin kullandıkları zorlayıc1 güç kaynağındaki 1 birimlik artışın örgütsel özdeşleşme üzerinde 0,084 değerinde bir azalışa neden olmasıdır. Nitekim yöneticilerin kullandıkları güç kaynakları, işgörenlerin örgütsel özdeşleşme düzeylerinde etkilidir.Bu durum; "otel işletmeleri yöneticilerinin kullandıkları güç kaynaklarının işgörenlerin örgütsel özdeşleşme algıları üzerinde anlamlı bir etkisi vardır" biçiminde geliştirilen araştırmanın hipotezinin desteklendiğini ortaya koymaktadır.

\section{Sonuç, Tartışma ve Öneriler}

Otel işletmelerinin başarılı olabilmesi için, çalışanların örgütsel özdeşleşme düzeyleri yüksek olmalıdır. Nitekim örgütsel özdeşleşmenin örgüt için olumsuz sonuçları olabilecek pek çok durumu olumluya çevirdiği görülmektedir. Kalemci Tüzün (2009), örgütsel özdeşleşme düzeyi arttıkça çalışanların iş doyumu düzeylerini arttığını ifade etmektedir. Popoola (2005), çalışmasında örgütsel özdeşleşme-iş doyumu arasında benzer sonuçlar olduğunu vurgulamaktadır. Örgütsel özdeşleşme düzeyi arttıkça işgörenlerin işten ayrılma niyetlerinde azalma görülmektedir (Solmaz, 2010, s. 40-41). Öte yandan örgütsel özdeşleşme çalışan performansına da olumlu etki edecektir (Bulut, 2015). Yapılan çalı̧̧malar örgütsel özdeşleşmenin örgüt çalışanları üzerinde olumlu etkileri olduğunu göstermektedir. Otel işletmelerinde işgörenlerin örgütsel özdeşleşme düzeylerinin yükseltilmesinin örgüte olumlu getirileri olacağı açıktır. Turunç ve Çelik (2010) yaptıkları araştırma sonucunda örgütsel özdeşleşme düzeyi yükseldikçe iş performansının da olumlu biçimde artış gösterdiğini ifade etmişlerdir. $\mathrm{Bu}$ sonuç örgütsel özdeşleşmenin örgüte olumlu etkileri olduğunu destekler niteliktedir. Otel işletmelerinde başarının elde edilebilmesi ve örgütün belirlediği hedeflere ulaşabilmesi için işgörenlerin örgütsel özdeşleşme duygularının yüksek olması gerekmektedir. Örgütle bütünleşmiş ve örgütün hedeflerini kendi hedefleri gibi benimseyen ve bu hedeflere ulaşabilmek için en iyi performansı ortaya koymaya çalışan işgören otel işletmelerinde başarının elde edilmesinde büyük pay sahibidir. Solmaz (2010), yaptığı çalışma sonucunda örgütsel özdeşlemenin olumlu etkilerini ortaya koymuştur. Buna göre örgütsel özdeşleşme düzeyi 
arttıkça çalışanların işten ayrılma niyetlerinin azaldığını ifade etmiştir (Solmaz, 2010, s. 40-41). Nitekim özdeşleşme olgusu örgütler için büyük önem taşımaktadır.

Otel işletmeleri işgörenleri üzerinde gerçekleştirilen çalışma sonucunda yöneticilerin kullandıkları güç kaynakları konusu ile ilgili bir değerlendirme yapılacak olursa, araştırmanın yürütüldüğü beş yıldızlı otel işletmelerindeki yöneticiler tarafından, beğeniye dayalı güç ve uzmanlık güç kaynağının diğer güç kaynaklarına göre daha fazla kullanıldığı belirlenmiştir. Öte yandan otel yöneticileri tarafından uzmanlık güç kaynağının daha az tercih edildiği görülmektedir. Oysa, yöneticilerin uzmanlık güç kaynağı kullanımı oldukça önem taşıyan bir husustur. Çünkü uzmanlık gücü, liderin sahip olduğu bilgi ve birikim neticesinde diğerlerini ikna gücünü ifade etmektedir. Bu güç kaynağının temelinde liderin alanında uzman olduğu düşüncesi yer almaktadır. Alanında uzman kişilerin otel yönetiminde etki sahibi olması otel işletmelerinin başarısı ve geleceği için olumlu etkiye sahiptir. Yöneticilerin kullandıkları güç kaynakları genel olarak değerlendirildiğinde, uzmanlık güç kaynă̆ının daha fazla kullanılması gerekmektedir. Uzmanlık gücünün liderin sahip olduğu bilgi, beceri, alanında uzmanlık ve diğerlerini sahip olduğu bilgiyle ikna edebilme potansiyeli olduğu bilindiği üzere bu güç kaynağının kullanılması daha olumlu sonuçlar doğuracaktır biçiminde değerlendirilebilir.

Araştırma evreni kapsamındakibeş yıldızlı otel işletmelerinde çalışan işgörenlerin özdeşleşme düzeyleri orta seviyede bir aritmetik ortalama değerine sahiptir. Örgütsel özdeşleşmenin örgütlerde ortaya çıkardığı olumlu durumlar düşünüldüğünde her iki il için de özdeşleşmenin orta düzeyde olması olumsuz bir durum olarak ifade edilebilir. Özdemir (2007), yaptığı çalışmasında örgütsel özdeşleşme ile iş doyumui arasındaki ilişkiyi incelemiş ve örgütsel özdeşleşme düzeyi arttıkça iş tatmin düzeyinin de artış gösterdiğini ifade etmiştir. Benzer bir çalışma Çırakoğlu (2010), tarafından örgütsel özdeşleşme ile iş doyumu arasındaki ilişkiyi belirlemek amacıyla yapılmıştır. Nitekim araştırma sonucunda örgütsel özdeşleşme ile iş doyumu arasında pozitif yönlü bir ilişki olduğu tespit edilmiştir. $\mathrm{Bu}$ durum örgütsel özdeşleşmenin iş doyumu üzerinde olumlu bir etkisi olduğu sonucunu ortaya çıkarmaktadır. Bulut (2015), örgütsel özdeşleşmenin çalışma performansını olumlu etkilediğini belirlemiştir. Demirci (2010), ise örgütsel güven ile örgütsel özdeşleşme arasında bir ilişki olduğunu ifade etmiştir. Örgütsel özdeşleşmenin örgüt çalışanları üzerindeki olumlu etkileri oldukça açıktır. Nitekim Topcu (2015), çalışmasında örgütsel özdeşleşmenin işten ayrılma niyetini üzerinde caydırıcı etkisini olduğunu ifade etmiştir. Bu durum örgütüyle bütünleşmiş çalışanların işten ayrılmayı düşünmedikleri biçiminde yorumlanabilir. Öte yandan örgütsel özdeşleşme konusuyla ilgili dikkat çekici bir çalışma olan ve Kesen (2016) tarafından gerçekleştirilen çalışmada örgütsel özdeşleşme ile bireysel yaratıcılık arasında anlamlı bir ilişki olduğu tespit edilmiş, örgütsel özdeşleşme düzeyi arttıkça bireysel yaratıcılık düzeyinin de artış gösterdiği vurgulanmıştır. Cüce, Güney ve Tayfur (2013), tarafindan yapılan bir çalışmada ise çalışanların örgütsel adalet algıları artış gösterdikçe örgütsel özdeşleşme düzeyleri de artmaktadır.

Özellikle örgütsel özdeşleşmenin oluşturulabilmesi için yöneticiye büyük görev düşmektedir. Yönetici örgüt içerisinde işleyişi sağlarken dikkatli olmak zorundadır. Sahip olduğu gücü en iyi biçimde kullanıp, çalışanların özdeşleşme duygularını oluşturabilmek örgütün başarılı olmasında temel etkendir. Örgütsel özdeşleşme duygusunun oluşturulamadığ 1 örgüt çalışanları olası bir yabancılaşma durumu içerisinde olabilirler. Nitekim otel işletmelerinde işgörenlerin otele yabancılaşması örgüt başarısını sekteye uğratacaktır.

Yapılan araştırma sonucunda otel yöneticilerinin kullandıkları güç kaynakları ile örgütsel özdeşleşme arasında anlamlı ilişki olduğu tespit edilmiştir. Bu sonuca göre yöneticilerin kullandıkları güç kaynaklarından olan uzmanlık gücü, beğeniye dayalı güç, ödüllendirici güç arttıkça işgörenlerin örgütsel özdeşleşme düzeyleri artmaktadır. Ancak yöneticinin zorlayıcı güç kaynağı ile örgütsel özdeşleşme arasında negatif yönlü ilişki olduğu görülmektedir. Buna göre yöneticinin zorlayıcı güç kaynağını kullanımının artması, işgörenlerin örgütsel özdeşleşme düzeylerinde azalışa sebep olmaktadır şeklinde ifade edilebilir. Elde edilen bu sonuçlar "otel işletmeleri yöneticilerinin kullandıkları güç kaynaklarının işgörenlerin 
örgütsel özdeşleşme algıları üzerinde anlamlı bir etkisi vardır" biçiminde geliştirilen araştırmanın hipotezini desteklediğini ortaya koymaktadır. Bu doğrultuda otel yöneticilerinin kullandığ 1 güç kaynaklarının işgören üzerinde bıraktığı etki ve bu etkinin örgütün geleceğine yön verdiği ortaya çıkmaktadır. Örgütsel özdeşleşme duygusunun yüksek olduğu işgörenler otel hedeflerini benimseyecek, elde edilecek başarıyı kendi başarısı gibi görecek ve olası bir olumsuz durumu kendi olumsuz durumu gibi değerlendirecektir. Dolayısıyla işgörenler, hizmet üreten ve bu hizmeti insan unsuru aracılığıyla müşterisine aktaran otel işletmelerinde daha büyük önem taşır. Örgütle özdeşleşen işgören yaptı̆̆ işi severek yapacak ve yaptığı işten elde ettiği doyum daha fazla olacaktır. Kalemci Tüzün (2009), çalışmasında örgütsel özdeşleşmenin iş doyumu üzerinde arttırıcı bir etkisi olduğunu ifade etmiştir. Otel işletmelerinde işgörenlerin işten doyum düzeylerinin yüksek olması üretilen hizmet kalitesinin arttırılmasına olumlu etki edecektir. Popoola'nın (2005) çalışması da benzer sonuçları göstermektedir. İşgörenlerin örgütsel özdeşleşme düzeyleri arttıç̧a iş doyum düzeyleri de artış göstermektedir. Çırakoğlu'nun (2010) çalışmasında ulaştığı sonuç aynıdır. Örgütsel özdeşleşme düzeyi yüksek olan işgörenler yaptıkları işten daha fazla doyum almaktadırlar. Örgütsel özdeşleşmenin sağlanması işgörenlerin işten ayrılma niyetlerini de etkileyecektir. Solmaz (2014) çalışmasında örgütsel özdeşleşmenin yüksek olduğu işgörenlerin işten ayrılma niyetlerinin düşük olduğunu ifade etmiştir. Topcu (2015) çalışmasında benzer sonuçları elde etmiştir. Örgütsel özdeşleşme düzeyi arttıkça işten ayrılma niyeti azalmaktadır. Tuna ve Yeşiltaş (2014) otel işletmeleri işgörenleri üzerinde gerçekleştirdikleri çalışmada örgütsel özdeşleşme arttıkça işten ayrılma niyetinin azaldığını belirtmişlerdir. Bu sonuç işgören devir hızını düşürülmesine doğrudan etki edeceği ve örgütü pek çok olumsuz durumdan kurtaracağı için önem taşımaktadır. Ancak örgütsel özdeşleşmenin sağlanması yöneticinin olumlu etkisi ile mümkün olabilecektir. Yönetici kullandığ1 güç kaynağını doğru biçimde seçmeli ve örgüte en uygun olan güç kaynağı ile örgütün işleyişini sağlamalıdır. Güç kaynakları kullanımında ve örgütsel özdeşleşmenin sağlanmasında dikkat edilmesi gereken bir diğer nokta örgütsel adalet unsurudur. Yönetici hangi güç kaynağını kullanırsa kullansın mutlaka adaletli davranmak zorundadır. Çünkü Cüce vd. (2013) çalışmalarında belirttiği gibi işgörenlerin örgütsel adalet algıları arttıkça örgütsel özdeşleşme düzeyi de artış göstermektedir. Bir diğer ifade ile işgörenler örgüt içerisinde adaletli bir yönetim uygulandığını düşündüklerinde örgütsel özdeşleşme duyguları artmaktadır. Turunç ve Çelik (2010) ise yaptıkları çalışmada örgütsel destek algılarının örgütsel özdeşleşme üzerinde olumlu etkisi olduğunu ve örgütsel özdeşleşmenin de işgören performansı üzerinde olumlu etkisi olduğunu ifade etmişlerdir. Cömert (2014) çalışmasında yöneticilerin kullandığı güç kaynaklarının örgütsel bağlılık üzerinde anlamlı bir etkisinin olduğunu belirtmiştir. Bu durum yönetim ve yönetici faktörünün örgüt içerisinde taşıdığı önemi bir kez daha ortaya çıkarmaktadır.

Çalışmada elde edilen bulgular doğrultusunda, literatüre, işletmelere ve ilgili taraflara ve bundan sonra araştırma yapacaklara birtakım öneriler getirilebilir. İlgili öneriler aşağıda sıralanmıştır:

- Konuyla ilgili olarak literatürde güç kaynakları konusu ile ilgili yapılan çalışmalara rastlamak mümkündür. Ancak güç kaynakları konusunun turizm sektöründe ve özellikle otel işletmeleri üzerinde geniş bir yer bulduğunu söylemek mümkün değildir. Bu doğrultuda öncelikle otel işletmelerinde güç konusunun önemine değinilmeli ve otel işletmelerinde güç kaynakları konusu kapsamlı biçimde ele alınmalıdır. Turizm sektöründe ve özellikle otel işletmelerinde güç kaynakları konusunun ele alınması hem işletmeye büyük fayda sağlayacak hem de yöneticilerin örgütün verimliliğinin arttırılabilmesi için en doğru güç stilini kullanmasını sağlayacaktır.

- Bu çalışmada otel yöneticilerinin en az uzmanlık güç kaynağını kullandığı görülmektedir. Uzmanlık gücü, liderin sahip bilgi ve alanında uzmanlığıyla ikna gücünü ifade eder. Nitekim uzmanlık güç kaynağının yöneticiler tarafından daha yaygın biçimde kullanılması gerekmektedir. 
- Yapılan çalışma sonucunda ödüllendirici güç kaynağının otel yöneticileri tarafından yüksek denilebilecek düzeyde kullanıldığı görülmektedir. Bu durum işgören üzerinde ödüle bağımlılık oluşturabileceği için otel yöneticilerinin dikkat etmesi gereken unsurlar arasındadır.

- Otel işletmeleri için önemli bir konu olan örgütsel özdeşleşme düzeyleri orta düzeyde tespit edilmiştir. $\mathrm{Bu}$ durum otel işgörenlerinin kendilerini örgüte tam anlamıyla ait hissedemediklerini göstermektedir. Dolayısıyla bu durum işgörenlerin örgütün hedeflerini benimsemelerine ve örgütün başarısı için etkin biçimde çalışmalarına engel teşkil edebilir. Bu durumun önüne geçebilmek için işgörenlerin özdeşleşme duygularının yüksek tutulması gerekmektedir. Otel yöneticileri, işgörenlerin örgütle bütünleşebilmelerini sağlayacak imkan ve olanaklar sunmalıdırlar. $\mathrm{Bu}$ bağlamda, örgütsel birliğin sağlanabilmesi ve örgütsel özdeşleşmenin oluşturulabilmesi için otel çalışanlarına değer verildiğini ortaya koyacak politikalara işlerlik kazandırması önerilmektdir. $\mathrm{Bu}$ doğrultuda ikna edici sosyal organizasyonlar gerçekleştirilmesi örgütsel özdeşleşmeye olumlu etki edebilir.

- Bu araştırma Afyonkarahisar ve Antalya illerinde gerçekleştirilmiştir. Daha geniş bir evrenle yapılacak çalışmalar sonuçların daha genellenebilir olması açısından önem taşımaktadır. $\mathrm{Bu}$ alanda benzer çalışmalar yapmak isteyenlere öncelikle yönetici görüşlerinin çalışmaya dahil edilmesi önerilebilir.

- Benzer çalışma yapmak isteyen araştırmacılar turizm sektörü açısından öncelikle güç kaynakları konusunda yoğunlaşmalı ve konunun sektör açısından sahip olduğu önem ve etkileri incelenmelidir. Ayrıca güç kaynaklarının iş tatmini, motivasyon, örgütsel adalet vb. konulara olan etkilerinin de incelenmesi önemlidir.

Sonuç olarak Afyonkarahisar ve Antalya ilinde faaliyette bulunan otel işletmeleri çalışanlarının görüşleriyle güç kaynakları, örgütsel özdeşleşme konularının incelendiği ve birbiriyle olan ilişkisinin ortaya konulduğu bu çalışmada, ilgili taraflara öneriler getirilmiştir. Yönetici sahip olduğu gücü gereği hem işleyişi sağlar hem de işgörenler üzerinde olumlu veya olumsuz izlenimler bırakır. Bu izlenimler örgüt içerisinde hedeflere ulaşılmasında pay sahibidir. Bu payı olumluya dönüştürebilmek için otel yöneticilerinin ellerinde bulundurdukları gücü etkin, örgütün verimliliğini artıracak şekilde ve örgüt işgörenleri üzerinde en olumlu izlenimi yaratacak biçimde kullanmalıdırlar. Bu husus, otel işletmelerinde otel yöneticilerinin sahip olduğu önemi ortaya koymaktadır. Otel yöneticileri işgörenleri üzerinde bırakacakları etki ile işgörenlerin örgüte karşı duygularının belirlemelerinde önemli etkiye sahiptirler. Dolayısyla hizmet üreten ve bu hizmet ile değerlendirilen otel işletmelerinde işgörenlerin örgütle bütünleşip özdeşleşme içerisinde olmaları ve örgütsel yabancılaşmanın en alt düzeyde tutulması hem işletmenin geleceği açısından hem de hizmet kalitesinin arttırılması açısından büyük önem taşır.

\section{Kaynakça}

Akbaba, A. ve Erenler, E. (2008). Otel işletmelerinde yöneticilerin liderlik yönelimleri ve işletme performansı ilişkisi. Anatolia: Turizm Arastırmaları Dergisi, 19(1), 21-36.

Akyüz, B. Kaya, N. ve Aravi, B. (2015). Kamu çalışanlarının iş tatmini üzerinde liderin güç kaynaklarının rolü/The role of the leader's power sources on public employees' job satisfaction. Çanakkale Onsekiz Mart Üniversitesi Yönetim Bilimleri Dergisi, 13(25), 71-90.

Babür, S. (2009). Turizm sektöründe örgütsel yabancılaşma: antalya beş yıldızl konaklama işletmelerine yönelik bir araştırma (Yayınlanmamış yüksek lisans tezi). Akdeniz Üniversitesi, Antalya.

Bağcı, Z. (2009). Örgütlerde çalışanların algıladıkları güç kaynaklarının örgütsel bağlllıkları üzerine etkisi: bir araştırma (Yayımlanmamış doktora tezi). Dokuz Eylül Üniversitesi, İzmir.

Bağcı, Z. ve Mahan Bursalı, Y. (2011). Yöneticilerin güç kaynaklarının çalışanların örgüte bağl1lıkları üzerine etkisi. Pamukkale Üniversitesi Sosyal Bilimler Enstitüsü Dergisi, 9, 9-21. 
Bulut, E. (2015). Personel güçlendirme, örgütsel özdeşleşme ve çalışan performansı arasındaki ilişki: katılım bankalarında araştırma (Yayınlanmamış yüksek lisans tezi). Beykent Üniversitesi, İstanbul.

Çakır Titizoğlu, Ö. (2011). Etkileşimci ve dönüşümcü liderlik tarzlarının örgütsel özdeşleşme ve iş tatmini üzerine etkisi: bir saha araştırması (Yayınlanmamış yüksek lisans tezi). Abant İzzet Baysal Üniversitesi, Bolu.

Çırakoğlu, H. (2010). Örgütsel özdeşleşme ve iş doyumu ilişkisi (Yayınlanmamış yüksek lisans tezi). Dokuz Eylül Üniversitesi, İzmir.

Cömert, M. (2014). Öğretmenlerin örgütsel bă̆llllk düzeyleri ile okul müdürlerinin kullandıkları örgütsel güç kaynakları arasındaki ilişkinin incelenmesi (Yayınlanmamış yüksek lisans tezi). Kahramanmaraş Sütçü İmam Üniversitesi, Kahramanmaraş.

Cüce, H., Güney, S. ve Tayfur, Ö. (2013). Örgütsel adalet algilarinin örgütsel özdeşleşme üzerindeki etkisini belirlemeye yönelik bir araştirma. H.̈̈. Íktisadi ve İdari Bilimler Fakültesi Dergisi, 31(1), 1-30.

Demir, K. (2017). Okul yöneticilerinin kullandıkları güç kaynakları ile öğretmenlerin sinizm düzeyleri arasındaki ilişski (Yayınlanmamış yüksek lisans tezi). İstanbul Sabahattin Zaim Üniversitesi, İstanbul.

Demirci, Ü. (2010). Örgütsel özdeşleşme ve örgütsel güvenin çalışan performansı üzerindeki etkisi (Yayınlanmamış yüksek lisans tezi). İstanbul Üniversitesi, İstanbul.

Dirik, D. (2017). Liderin sosyal güç kaynakları ile çalışan performansı ve liderin etkililiği arasındaki ilişkiler: cinsiyet perspektifinden bir araştırma (Yayınlanmamış doktora tezi). Manisa Celal Bayar Üniversitesi, Manisa.

Erdoğan, B. (1997). Örgütsel güç ve politika. Yönetim Dergisi, 8(26), 21-31.

Erkutlu, V. (2003). yöneticilerin güç kaynakları ve bunların yönetici ve örgütsel etkililik üzerindeki etkileri: beş yıldızlı oteller üzerinde bir uygulama (Yayınlanmamış doktora tezi). Gazi Üniversitesi, Ankara.

Fodor, E. M. (1985). The power motive, group conflict, and physiological arousal. Journal of Personality and Social Psychology, 49, 1408-1415.

French, J. P. \& Raven, B. (1959). The bases of social power. In Dorwin Cartwright (Ed.), Studies in social power (pp. 150-167). Ann Arbor, MI: Institute for Social Research.

Green, R. D. (1999). Leadership as a function of power. Proposal Management, 54-56.

İşcan, Ö. F. (2006). Dönüştürücü/Etkileşimci liderlik algısı ve örgütsel özdeşleşme ilişkisinde bireysel farklılıkların rolü. Akdeniz Üniversitesi İktisadi ve İdari Bilimler Fakültesi Dergisi, 6(11), 160-177.

Kalemci Tüzün, İ. (2006). Örgütsel güven, örgütsel kimlik ve örgütsel özdeşleşme ilişkisi: uygulamalı bir çalışma (Yayınlanmamış doktora tezi). Gazi Üniversitesi, Ankara.

Kalemci Tüzün, İ. (2009). The impact of identification and commitment on job satisfaction. Management Research News, 32(8), 728-738.

Karalar, S. (2015). Ödül yönetiminin örgütsel özdeşleşme ile işgücü atikliği üzerine etkisi ve bir araştırma. (Yayınlanmamış doktora tezi). Trakya Üniversitesi, Edirne.

Kayalı, M. (2011). Okul müdürlerinin kullandıkları güç kaynakları (Uşak ili örneği) (Yayımlanmamış yüksek lisans tezi). Uşak Üniversitesi, Uşak. 
Kesen, M. (2016). Linking organizational identification with individual creativity: organizational citizenship behavior as a mediator. Journal of Yaşar University, 11(41), 5666.

Köse, C. G. (2009). Örgütsel özdeşleşmenin çalışanların sürekli iyileştirme çabalarına katkısı: bir araştırma (Yayınlanmamış yüksek lisans tezi). İstanbul Üniversitesi, İstanbul.

Mael, F. A. \& Ashforth, B. E. (1992). Alumni and their alma mater: a partial test of the reformulated model of organizational identification. Journal of Organizational Behavior, $13(2), 103-123$.

Özdamar, K. (2003). Modern bilimsel araştırma yöntemleri (1. Baskı Yayın No: 5). Eskişehir: Kaan Kitabevi.

Özdemir, H. Ö. (2007). Çalışanların kurumsal sosyal sorumluluk algılamalarının örgütsel özdeşleşme, örgütsel bağlllık ve iş tatminine etkisi: opet çallşanlarına yönelik uygulama (Yayınlanmamış doktora tezi). Marmara Üniversitesi, İstanbul.

Özhan, T. (2016). Okul müdürlerinin kullandıkları güç kaynakları ile ögretmenlerin örgütsel güven düzeylerine yönelik görüşleri arasındaki ilişki (Yayınlanmamış yüksek lisans tezi). Düzce Üniversitesi, Düzce.

Özsöylemez, O. (2009). Algılanan liderlik tarzlarının iş tatmini ve işten ayrılma niyeti üzerindeki etkisinde örgütle özdeşleşmenin rolü (Yayınlanmamış yüksek lisans tezi). Marmara Üniversitesi, İstanbul.

Pelit, E. (2015). Turizm işletmelerinde insan kaynakları yönetiminin önemi. E. Pelit, (Ed.), Turizm işletmelerinde insan kaynakları yönetimi (1.Bask1) içinde (ss. 61-127). Ankara: Grafiker Yayınları.

Polat, M. (2009). Örgütsel özdeşleşmenin öncülleri ve ardılları üzerine bir saha çalışması (Yayınlanmamış doktora tezi). Uludağ Üniversitesi, Bursa.

Popoola, J. K. (2005). Organizational identification and commitment as correlates of job satisfaction (Doktora tezi). Washington DC Howard University.

Rahim, M. A. (1988). The development of a leader power inventory.multivariate behavioral research, 23, 491-503.

Schermerhorn, J. R. Hunt, J. G. \& Osborn, R. N. (1997). Organizational behavior. (6.Bask1). USA: John Wiley And Sons, Inc.

Solmaz, H. (2010). Örgütsel özdeşleşmenin işten ayrllma niyetine etkisinde örgütsel adaletin aracılık rolü (Yayınlanmamış yüksek lisans tezi). Ufuk Üniversitesi, Ankara.

Topcu, M. K. (2015). Çalışanların kişilik özelliklerinin örgütsel özdeşleşme ve işten ayrılma niyeti üzerine etkisindepsikolojik sözleşme algısının rolü (Yayınlanmamış doktora tezi). Kara Harp Okulu, Ankara.

Tuna, M. ve Yeşiltaş, M. (2014). Etik iklim, işe yabancılaşma ve örgütsel özdeşleşmenin işten ayrılma niyeti üzerindeki etkisi: otel işletmelerinde bir araştırma. Anatolia: Turizm Araştırmaları Dergisi, 25(1), 105-117.

Türk Dil Kurumu, (2017). Güç'ün kelime anlamı. (Erişim Tarihi: 06.03.2017), http://tdk.gov.tr/index.php?option=com gtsvearama=gtsveguid=TDK.GTS.5c1fa0447ee460.74100824.

Turunç, Ö. ve Çelik, M. (2010). Çalışanların algıladıkları örgütsel destek ve iş stresinin örgütsel özdeşleşme ve iş performansına etkisi. Yönetim ve Ekonomi: Celal Bayar Üniversitesi İktisadi ve İdari Bilimler Fakültesi Dergisi, 17(2), 183-206. 
Ural, A. ve Kılıç, İ. (2013). Bilimsel araştırma süreci ve spss ile veri analizi (4.Baskı). Ankara: Detay Yayıncilik.

Wong, S. Siu, V. \& Tsang, N. (1999). The impact of demographic factors on hong kong hotel employees' choice of job-related motivators. International Journal of Contemporary Hospitality Management, 11(5), 230-242.

Yaman, T. (2011). Yöneticilerin paternalist (babacan) lider davranışlarının çalı̧̧anların örgütsel özdeşleşmelerine, iş perfromanslarına ve işten ayrllma niyetlerine etkisi: özel sektörde uygulama (Yayınlanmamış yüksek lisans tezi). Kara Harp Okulu, Ankara.

Yarmac1, N. (2012). Psikolojik güçlendirmenin örgütsel özdeşleşmeye etkisi: otel işletmelerinde bir araştırma (Yayımlanmamış yüksek lisans tezi). Afyon Kocatepe Üniversitesi, Afyonkarahisar.

Yeşiltaş, M. (2012). Örgütsel özdeşleşmenin oluşmasinda belirleyiciler olarak etik liderlik ve etik iklim: otel işletmelerine yönelik bir uygulama (Yayınlanmamış doktora tezi). Gazi Üniversitesi, Ankara.

\section{ETİK ve BİLIMSEL İLKELER SORUMLULUK BEYANI}

$\mathrm{Bu}$ çalışmanın tüm hazırlanma süreçlerinde etik kurallara ve bilimsel atıf gösterme ilkelerine riayet edildiğini yazar(lar) beyan eder. Aksi bir durumun tespiti halinde Afyon Kocatepe Üniversitesi Sosyal Bilimler Dergisi'nin hiçbir sorumluluğu olmayıp, tüm sorumluluk makale yazarlarına aittir. Yazarlar etik kurul izni gerektiren çalışmalarda, izinle ilgili bilgileri (kurul adı, tarih ve sayı no) yöntem bölümünde ve ayrıca burada belirtmişlerdir.

Kurul adı: Afyon Kocatepe Üniversitesi Bilimsel Araştırma ve Yayın Etiği Kurulu

Tarih: 28.10.2016

No: $2016 / 110$

\section{ARAŞTIRMACILARIN MAKALEYE KATKI ORANI BEYANI}

1. Yazar katkı oran1 : \%50

2. Yazar katkı oranı : $\% 50$

Bu çalışma Afyon Kocatepe Üniversitesi, Bilimsel Araştırma Projeleri Koordinasyon Birimi Başkanlığı tarafından desteklenmiştir. Proje No: 16.SOS.BİL.11 